\title{
Flame structures and ignition characteristics of torrefiedand raw sewage sludge particles at rapid heating rates
}

\section{ChinsungMock $^{\mathrm{a}}$, HookyungLee ${ }^{\mathrm{b}}$, SangminChoi ${ }^{\mathrm{b}}$, Vasilije Manovic ${ }^{\mathrm{a},{ }^{*}}$}

a,* Combustion and CCS Centre, Cranfield University, Cranfield, Bedfordshire MK43 0AL, United Kingdom. Tel.: +44(0)1234 754649; fax: +44 1234751671.

E-mail address: v.manovic@cranfield.ac.uk (V. Manovic). 


\title{
Flame structures and ignition characteristics of torrefiedand raw sewage sludge particles at rapid heating rates
}

\author{
ChinsungMock ${ }^{\mathrm{a}}$, HookyungLee ${ }^{\mathrm{b}}$, SangminChoi ${ }^{\mathrm{b}}$, Vasilije Manovic ${ }^{\mathrm{a},{ }^{*}}$ \\ ${ }^{\mathrm{a}}$ Centre for Combustion and Carbon Capture and Storage, Cranfield University, Cranfield, \\ Bedfordshire MK43 0AL, United Kingdom \\ ${ }^{\mathrm{b}}$ Department of Mechanical Engineering, Korea Advanced Institute of Science and \\ Technology (KAIST), Daehak-ro, Yuseong-gu, Daejeon, South Korea.
}

Corresponding author: V. Manovic, Email: v.manovic@cranfield.ac.uk, Tel: +44(0)1234 754649

\begin{abstract}
Torrefactionis a promising method for improving the quality of pulverised solid fuel, as itincreases the flame stability,radiative heat transfer and energy density of the fuel.Raw sewage sludge contains less fixed carbon and more ash compounds than other biomasses; consequently, it has poorenergy quality witha long ignition delay and forms arelatively low, sooty flame. In this study,we directly investigate the combustion behavioursof particles with varying degrees of torrefaction by burning them at $1340 \mathrm{~K}$. Thetorrefied particles were prepared at different temperatures $(473 \mathrm{~K}$ or $573 \mathrm{~K})$ for different residence times (10minor 30min).The experimental parameters examined were the size range of the particles (150$215 \mu$ mand $255-300 \mu \mathrm{m})$ and the $\mathrm{O}_{2}$ percentage $(10-40 \%)$. The particles wereentrained from a
\end{abstract}


cold carrier gas into a hot gas stream, igniting a volatile flame that was extinguished a few millisecondslater. These temporal variations in the burning particles weredetected byin-situ high speed photography (7000 frames/s). Thetorrefactiondegree affected the flame structure and varied the ignition delay, due to the mismatched reactivity and soot formation at rapid heating rates. The mosttorrefied sludge particlesexhibited a relatively luminous volatile cloudand a large flame, while preserving the duration of volatile combustion. These observations confirm theimproved pulverised combustion of the torrefied sludge particles. We also obtained valuable flame parameters (radius, intensity and combustion time) of the differentlytorrefied sludge particles.

\section{Introduction}

The devolatilisation and char oxidation rates, ignition delays and burnout times of burning solid fuel particles largely depend on the surrounding conditions [1, 2]. The hot gas temperature, rapid heating ratesand oxygen concentration contribute to discrepantignition delaysand flame intensities $[3,4]$.Fast pyrolysis increases the soot production from solid fuel particles, particularly at high temperatures, whensoot is relatively more reactive $[5,6]$. Such reactivity, along with the high volume fraction of soot particles,greatly influences thecombustion performance inindustrialapplications, because sooty flamesradiate large amounts of heat. In general,pulverised solid fuel particles immediately reach high temperatures during combustion, forming a sooty flame with release of volatile matter, tar, soot and ash in the early stages [7,8]. Moreover, this formation is strongly associatedwiththe physical structures and chemical compositions of the fuels, which varyparticularly in their biomass particles [9].However,the physicalproperties of volatile flames may not be clearly

described in observations, as micron-sized particles burn very quickly in 
industrialenvironments.

Utilisation of biomass and waste materialscanreduce the environmental problemscaused byhigh carbon dioxide emissions, which are mainly generated from burning fossil fuels. Therefore, clean and renewable energy sources are strongly desired $[10,11]$ and sewage sludge is currently accepted as a low-cost material for pulverised biomass combustion [12, 13]. For economic reasons, this waste material has been dispensed into landfills or the ocean. However,such waste alsocontains large quantities of accumulated heavy metals, toxins and dioxin compounds, which contaminate the environment[14]. The direct use of sewage sludge in agriculture could also be risky because of pathogenic transfer to crops $[15,16]$ and many EU countries have banned the spreading of this waste on land [17]. Since 1993, international treaties have banned ocean disposal of wastes such as sewage sludge. Incineration or combustion might be an alternative option to consume this solid waste and to generate heat, although there are disagreements in regards the emission of heavy metals [18]. In fact, $\mathrm{Cu}, \mathrm{Ni}$, $\mathrm{Pb}$ and $\mathrm{Cd}$ can be volatilised at high temperatures in hot gas and emitted to the atmosphere. The volatility of these heavy metals is enhanced by chlorine, which is present in the sewage sludge $[19,20]$. Therefore, some researches $[21,22]$ suggested that these heavy metals can be condensed using additional chlorinating agents and electrostatic ash precipitators.

The combustion behaviour ofsewage sludge radically differs from that of general lignocellulose biomass, because sewagecontains low hemicellulose and cellulose components and incombustible high ash content [23]. Sludge particlesburn with a low luminous flame and have a long ignition delay. Both properties are considered disadvantageous in pulverised combustion.Generally, the heat energy radiated by the highly luminous flame exerts a positive effect,although the release of unburned soot might also generate air pollution [24, 25]. The low-soot flame of raw sludge particlesimproves with increasing particle size. 
However, pulverised combustion limits the particle size distribution, as a large particle mass cannot completely burn within a certain time[26]. For this reason, the fuel combustion quality of raw sludge particlesneeds improvement.

A potential solution is offered by torrefaction, which transforms the sludge particles into coal-like solid fuel particles. In previous research [27, 28], torrefied biomass particles were obtained at surrounding gas temperatures between 473 and $623 \mathrm{~K}$. Thethermal treatment chemically converts oxygen to $\mathrm{CO}$ and $\mathrm{CO}_{2}$ and reduces the $\mathrm{O} / \mathrm{C}$ rate while increasing the energy density and hydrophobicity [29].In addition, the chemical and physical decompositions in torrefactionalter the reactivity, improve the flame stability and shorten the ignition delay of the fuel particles[30].The grindability and flowability of the torrefied particles might be improved by deforming the hemicellulose, which exists as fibrous structures in theparticles. Theeffects of torrefactionhave been extensively researched, but the analyses have been limited to thermogravimetricanalyses, which determine only the reactivity of lignocellulosic biomass materials [31-33]. These studies were limited to investigate the actual flame structures on the torrefied sludge particles.

This study investigates the apparent structure of the soot flame in terms of the boundary of pyrolysis and soot formation. The morphologies of the properties in the flame are also discussed from the captured images. The variations in structural flame properties, such asthedimensions, intensity and combustion timeof the soot flame, are demonstrated in a wellcontrolled single particle reactor. The study also compares theintrinsic ignition delays and combustion times of raw and torrefiedsludge particles and discusses the effects of pre-thermal treatment conditions (temperature and residence time)on the burning characteristics of the torrefied particles. Such experimental results enable discussions on describing the modelling of single waste particle combustion. 


\section{Experimental Section}

\section{Sewage sludge characterisation and particle separation for single particle combustion}

The proximate and ultimate analyses of raw sludge particlesareshown in Table 1.Sludge particles containa lower volume fraction of volatile matter and more ash content than wood particles. Table 2 presents the organic chemical compositions of standard biomass particles. The cellulose and hemicellulose contents are much lower in sludge particles than in wood particles and the lignin content is slightly lower. The sum of these three components in the sludge is approximately $30 \%$ (organic fraction) because of the high proportion of crude protein and ash (inorganic fraction) contained in it.As each of these substances decomposes within a different temperature range, the burning behavioursof sewage sludge and wood particles are expected to be dissimilar. Specifically, hemicellulose and cellulose are thermally degraded at $493-588 \mathrm{~K}$ and $588-673 \mathrm{~K}$, respectively,whereas lignin degrades over a wide temperature range $(423-1,176 \mathrm{~K})[34]$.

Table 1.Proximate and ultimate analyses of raw and torrefiedsewage sludge.

\begin{tabular}{|c|c|c|c|c|}
\hline \multirow{2}{*}{ Sample } & \multicolumn{4}{|c|}{$\begin{array}{l}\text { Proximate analysis } \\
\text { (wt. } \% \text { ar) }^{1}\end{array}$} \\
\hline & V.M & F.C & Ash & M \\
\hline Raw sewage sludge & 61.2 & 7.89 & 25.0 & $5 . !$ \\
\hline Torrefied sludge $(473 \mathrm{~K}, 10 \mathrm{~min})$ & 55.8 & 12.2 & 30.1 & $1 . t$ \\
\hline Torrefied sludge $(573 \mathrm{~K}, 10 \mathrm{~min})$ & 47.4 & 18.7 & 32.1 & 1.' \\
\hline Torrefied sludge $(573 \mathrm{~K}, 30 \mathrm{~min})$ & 32.1 & 28.9 & 37.3 & 1.4 \\
\hline Pine Wood (Ref) & 81.5 & 9.7 & 0.1 & $8 .:$ \\
\hline
\end{tabular}


Table 2.Organic compositions of sewage sludge and wood.

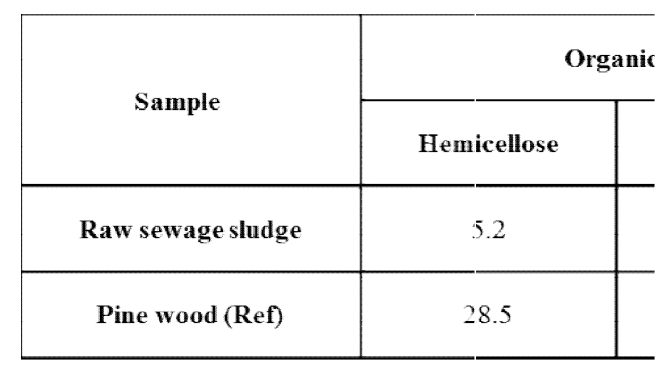

This study explores the effect of torrefactionon raw sewage particles. The surrounding gas temperature and residence time of thethermal treatmentsare given in Table. 3.The volatile matter fraction should decrease withincreasing carbon ratio during the torrefaction process. Physically, raw sludge particles resemble a stiffclay with numerous surface cracks from which the moisture has been previously removed. The particlesare brittle and irregularly shaped even after the pulverising process. Therefore, the particle separation is a three-step process of pulverisation, sieving and friction separation. The friction separator contains differently inclined planes that separate out the spherical particles by means of theirtranslational and rotational motions. Shapes such as extremely flat and cylindrical particles, are inappropriate for this experiment becausetheir varying drag coefficients cause random trajectories. Lee et al. [38] reported statistical variations of the particle trajectories in this cross flow mixing configuration, which indicated the probability distribution of the irregular burning particle for the experimentalreproducibility. The dynamic motion and trajectories of the particle were influenced by the ignitionbehaviour.

Table 3.Thermal treatment conditions of sewage sludge. 


\begin{tabular}{|l|l}
\hline & Torrefactiol \\
\hline 2\# torrefied sewage sludge & \\
\hline 3\# torrefied sewage sludge & \\
\hline 4\# torrefied sewage sludge & \\
\hline
\end{tabular}

The sewage sludge particles were prepared in two size groups;150-215 $\mu \mathrm{m}$ and $255-300 \mu \mathrm{m}$. Generally, a biomass particle has a lower particle density, a smaller volatile flame size and less luminosity, compared with a coal particle and, to detect their apparent flame, a biomass particle size over $150 \mu \mathrm{m}$ is required depending on the type of biomass [35].Coal particles inpulverised combustion are normally below $100 \mu \mathrm{m}$ [36]. However, sludge particles of this size burn with barely observable or invisible flames.

\section{Experimental set-up with cross-flow configuration at rapid heating rate}

Thehigh temperatures and rapid heating rates $\left(10^{4}-10^{5} \mathrm{~K} / \mathrm{s}\right)$ in this experiment were similar to those of industrial furnaces [37]. The set-up consisted of a pre-heated reactor, a honeycomb burner,a flow straightener and a water-cooled injector(see Figure.1).The reactor was a slab of rectangular quartz with dimensions of $(45 \times 45 \times 800) \mathrm{mm}^{3}$, equipped with a guard heater and an insulator. The honeycomb burner produced a high surrounding gas from the bottom with upward flow of $1 \mathrm{~m} / \mathrm{s}$. To analyse particle combustion behaviours, the velocities of the upward-flowing and the leftward-flowing streams are constant in all experiments. The ceramic honeycomb flow straightener installed above the burner maintained a laminar gas flow. The water-cooled injector, which maintained a cold carrier gas at $298 \mathrm{~K}$, was placed at the middle and left sides of the quartz. This layout allowed a cross-flow configuration in the reactor. The cold carrier gas was supplied at $2.6 \mathrm{~m} / \mathrm{s}$, entraining the particles into the highly mixed main stream in the test section. The particle injection configuration enables a relevant description 
of a sequential burning process withan apparent flame structure and direct quantitative observations of the burning particles as functions of time and displacement.

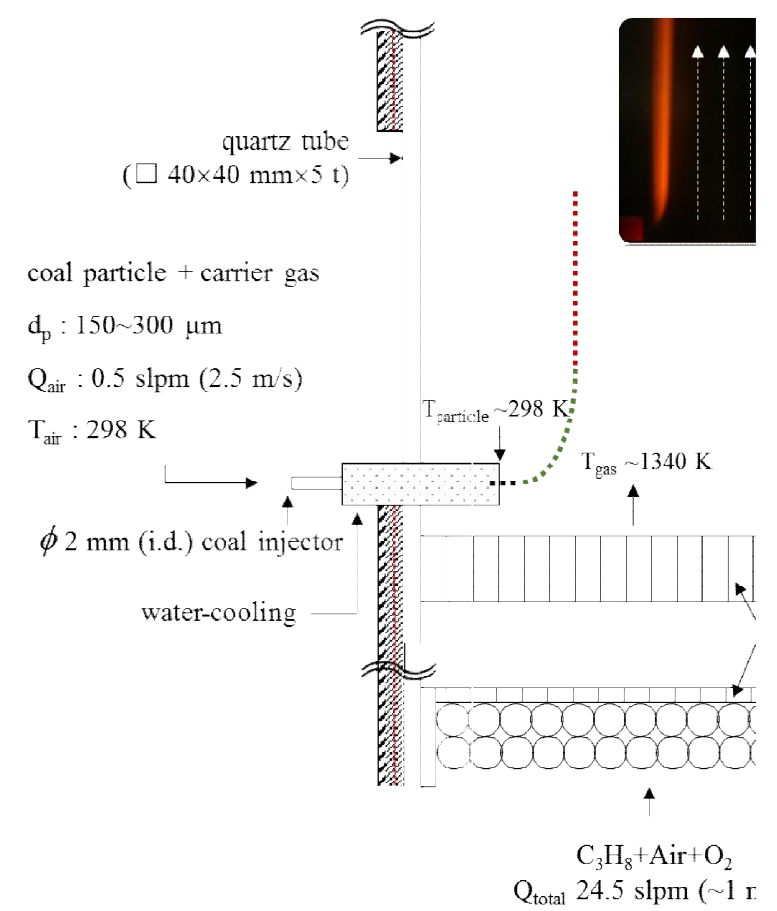

Fig1.Cross-flow configuration in the entrained flow reactor under well-controlled conditions. Single fuel particles are entrained into the $1,340 \mathrm{~K}$ zone from the water-cooled injector maintained at $298 \mathrm{~K}$.

\section{Direct observation of particle combustions}

To investigate the combustion events, the burning particles were directly observed by a high-speed camera (Phantom V710). The camera records randomly moving particles at 7,000 frames per second in $1,280 \times 800$ pixels. The relatively large sludge particles were captured by a $105-\mathrm{mm}$ micro focal lens and the pixel size was measured as $58 \mu \mathrm{m}$ by calibration. The details of this observational technique are explained in ref. [35].

Conditions in the surroundingenvironment and measurement of temperature and velocity 


\section{profiles}

To examine the effect of oxygen diffusion rate, the particles were exposed to $\mathrm{O}_{2}$ with volume fractions of 10 to $40 \%$. The post-combustion gas, $\mathrm{C}_{3} \mathrm{H}_{8}$, yields flue gases such as $\mathrm{N}_{2}$ (38.2-67.9vol\%), $\mathrm{O}_{2}(10.4-40.1 \mathrm{vol} \%), \mathrm{H}_{2} \mathrm{O}(12.4 \mathrm{vol} \%)$ and $\mathrm{CO}_{2}(9.3 \mathrm{vol} \%)$. The flow rates of the post-combustion gas and the cold carrier gas at the injector were 24.5 and $0.5 \mathrm{~L} / \mathrm{min}$, respectively. The particles were heated in the highly-mixed temperature zone created by the markedly different temperatures of the upward- and leftward-flowing streams. Within this zone, the initial combustion behaviourwas determined. The gas temperature profiles from the experimental measurement and numerical simulation are plotted in Figure2.In both methods, we evaluated the initial gas temperature and velocity as the particles were heated and investigated the highly-mixed turbulent region. These factors are essential for studying the ignition and combustion times. The numerical simulation, which computed the horizontal and vertical velocities and the gas temperature distribution over a wide range of the visualisation field, was carried out in FLUENT 14.0.Similar results of temperature and velocity in the reactor were shown in ref. [38]. The maximum temperature was $1,340 \mathrm{~K}$ at the centre. The sides were uninsulated (and hence experienced large heat losses) because an unobstructed field of view is necessary to allow particle observation. To combat the effect of these losses, the injector waspositioned at $10 \mathrm{~mm}$ fromthe $\mathrm{x}$-axis, wherethe temperature gradient was acceptably small. Therefore, the particlespassed through the gas stream between 10 and $30 \mathrm{~mm}$. Thetemperature profile predicted by the numerical analysis agreed well with the experimental results.Figure 3 showthenumerically calculated horizontal velocity profile of the flow velocity.The particles gained momentum in the leftward-flowing direction,but theirparticle velocityin the horizontal direction rapidly decreasedwhen the particles were carried up the reactor. 
(a)

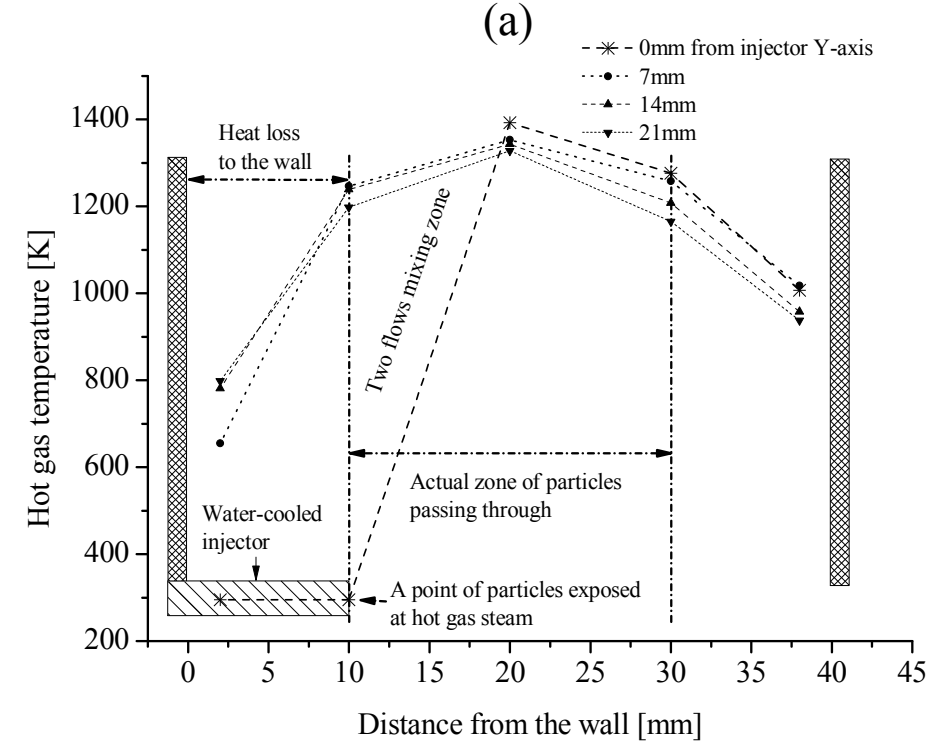

(b)

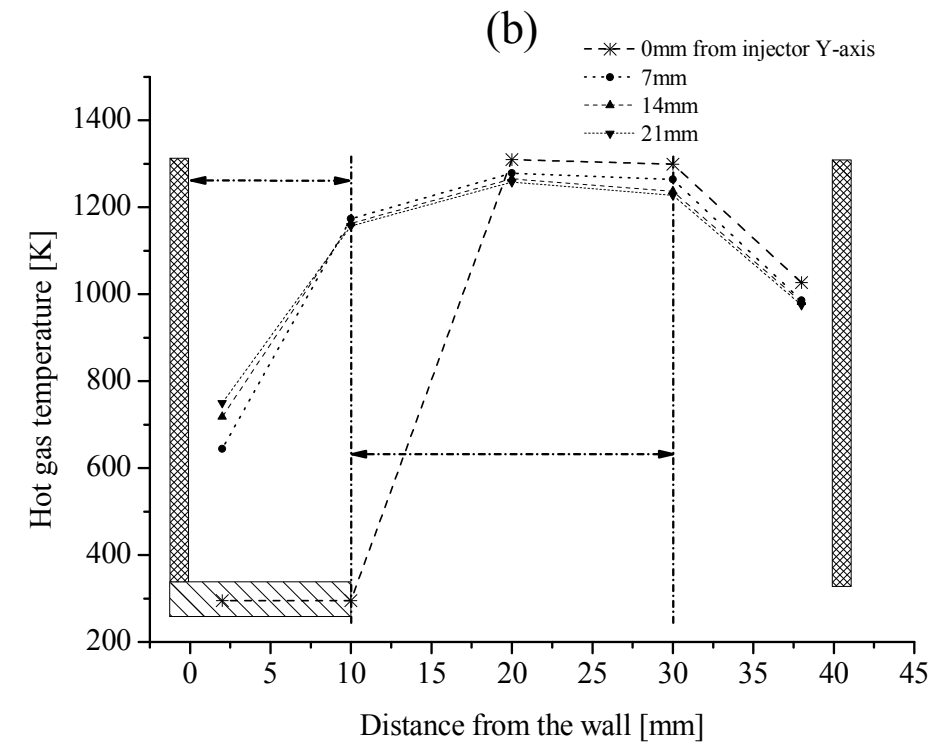

Fig.2.Gas temperature profiles obtainedby (a) experimentalmeasurement and (b) numerical simulation. The high heat loss at the sides is caused by the exposed field of view. To combat these losses, the injector is placed $10 \mathrm{~mm}$ fromthe wall. 

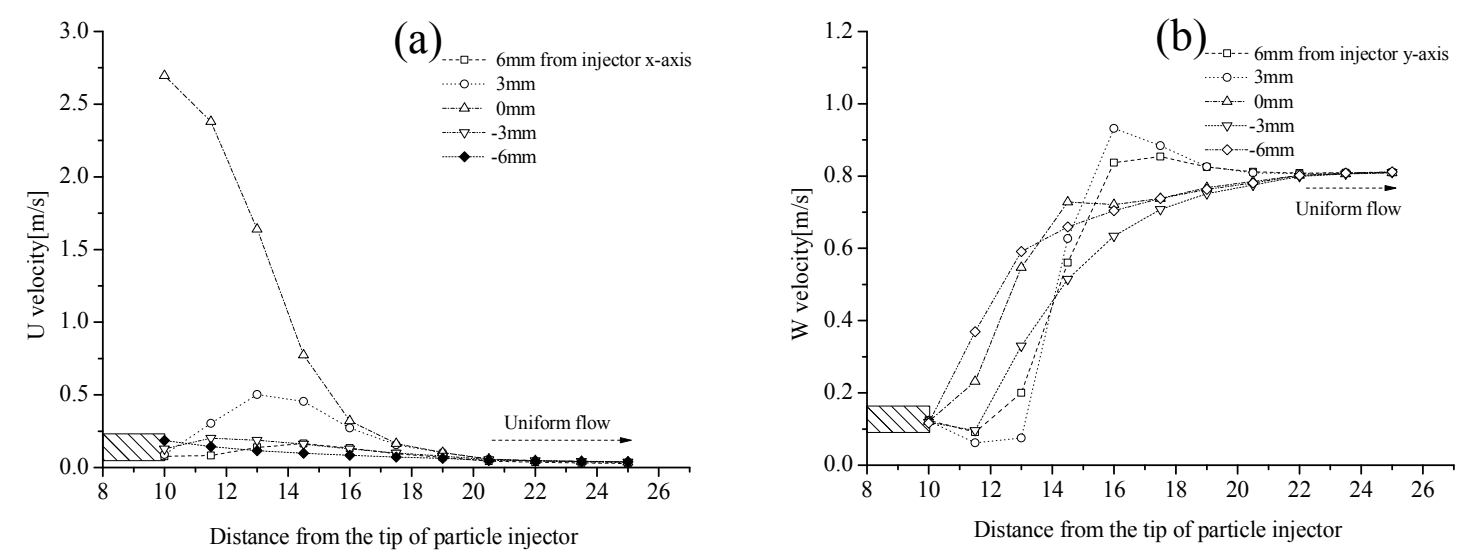

Fig.3.Gas velocity profilesaround the mixing zone, obtained in the numerical simulation: (a) horizontal velocity (b) vertical velocity.

\section{Formation of standard flame with boundaries of pyrolysis and soot formation}

The volatile flame is an elongated formation of sooty cloud several times largerthan the particlesthemselves[39, 40]. It is believed that the detailed mechanism of volatile cloud formation and its flame composition remains questionable because the complicatedtransportand hundredsof chemical events are difficult to quantify.Particularly, the detailed information of soot formation in phenomenological studies of carbonaceous particles is still being debated,because of the dependency between theparticles and the combustion system. To simplify the mechanism, we can regard a soot flame as a collection of volatile matter and submicron soot particles that follow several chemical reactions.During the primary pyrolysisreleases, light gases, char and heavy molecular weight hydrocarbons (mainly tar)are released [41]. These liquid-like materialsrandomly agglomerate into large clusters before cracking and polymerising. During the secondary reaction, tar converts to soot particles, especially at high temperature [25]. Soot particlesare composed of 20-50nmspherules that coagulate and agglomerate[42].Ma et al.[43]reported soot aggregates of5- 
$\mu \mathrm{m}$ diameter in a coal flame. A volatile flame isgenerally defined by the boundaries of the pyrolysis and soot formation within the combustion region. These boundaries are described as a simple flame sheet (see Figure4). During pyrolysis, carbonaceous particles of different sizesmix at different rates with organic particles, tar balls and a small number of the initial soot particles $[44,45]$. However, the general description of these compositions cannot be elucidated, as it depends on thetypes andtemperatures of the particles. Within the flame sheet, the volatile flame apparently divides into aninner core and an outer shellin the diffusion flame. The primary reaction occurs in the inner core, $\mathrm{r}_{\mathrm{i}}$,atransparent flameregion whose dimensionsare determined by the devolatilisation rate, oxygen concentration and particle size and temperature. The outer shell, $r_{s}$,is a luminous flame region that deposits many aggregates of soot particles through secondary reaction and transport. Finally, the flame edge is a region of secondary combustiondriven byoxidation of the volatile phase.
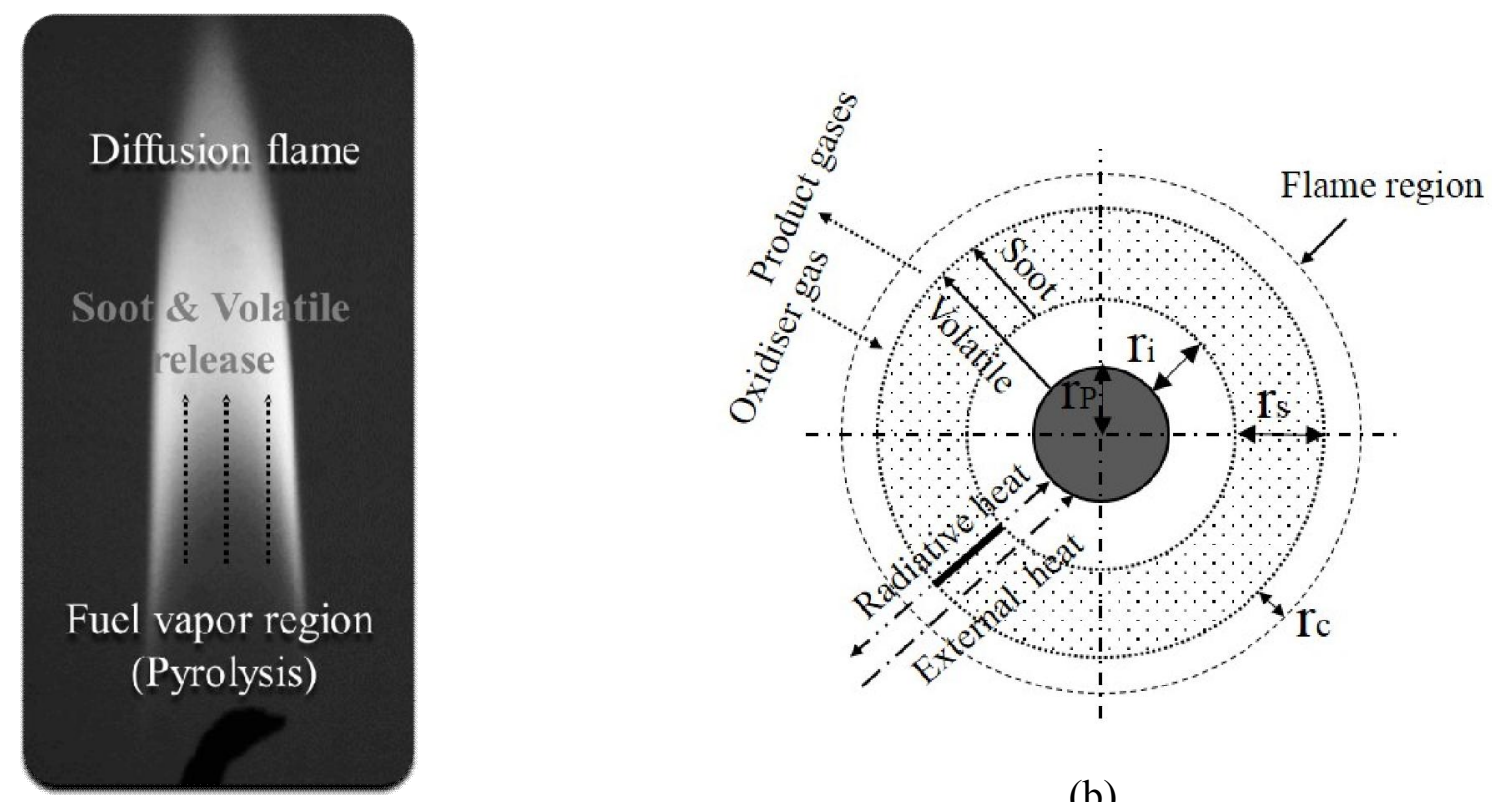

(b)

(a)

Fig.4. General flame structure of a candle: (a) boundaries of pyrolysis and soot formation showing the combustion region; (b) representative diffusion flame sheet 


\section{Results and Discussion}

\section{Optical carbonaceous particle properties in a flame}

To better understand the physical mechanism of flame formation by torrefied sludge particles, we observed the optical flame properties using a manual aerosol collector with a plate. Thevolatile flame on the pulverised particleswas too small for sampling, so we detected the flame of a pelletised particle. The following is an explanation for the procedure. The torrefied particle swiftly departed from the quartz when burned at $1340 \mathrm{~K}$. Within onesecond, aplate was passed through the pyrolysis zone in the flame. The samples were then transferredto the microscopefor particle detection. The transfer needed to be completed within 60 seconds; otherwise, most of theorganic particles and tar would evaporate. Several photographic images were acquired under varied displacements of the plate, acquiringdifferentproperties of the particles between the pyrolysis and soot formationboundaries. Micron and sub-micron carbonaceous particles were observed under Nikon microscopes (ECLIPSE E200) and imaged by amulti-output digital microscope camera (Moticam 2300).

The micrographsin Figure5show the varying size, shape and brightness of the volatile organic and non-volatile particles, tar balls and aggregates of the soot particles. Agglomerates of non-volatile and soot particles appear very bright, as these carbonised particles reflect light from halogen (lighting) illumination. The firstimage, takenin thecentre of the pyrolysis boundary,capturesa number of organic particles with various shapes and sizes. The bright central regions of these sub-micron particlesare probably sourced from sulphur, potassium, silicon and sodium, perhaps introduced through ageing of the organic particles. Consistent with this idea, previous observations [46]revealed no inclusions inthe initial organic particles. 
Novakovet al.[47]reported that these organic particles contribute to cloud nucleation. Cloud condensation nuclei are useful for determining the importance of inorganic components [48]. The second image shows the irregular shapes of non-volatile particles nearbythe shrunken organic particles. Older organic particles enhance the formation of tar balls fromnon-volatile particles. Tar balls form a chain-like arrangement around theorganic particles, as alsoreported by Kennedy [49] and Arora[50]. The third image captures the outer boundary of the pyrolysis. This region contains agglomeratedtar balls and non-volatile particles and near-extinctaged organic particles. Interestingly, the tar balls are grey in the previous image, but black in this image. However, the significance of this visual transformation needs verifying in highresolution images, so cannot be discussed here.The finalimage also captures theouter pyrolysis boundary, wheresoot formation produces a very sooty flame. The bright features are highly aggregated soot particlesthatmight have sequentiallyconverted from clusters of tar balls. These aggregates are nearly $1-3 \mu$ macross, but appear to be incompletely developed. 


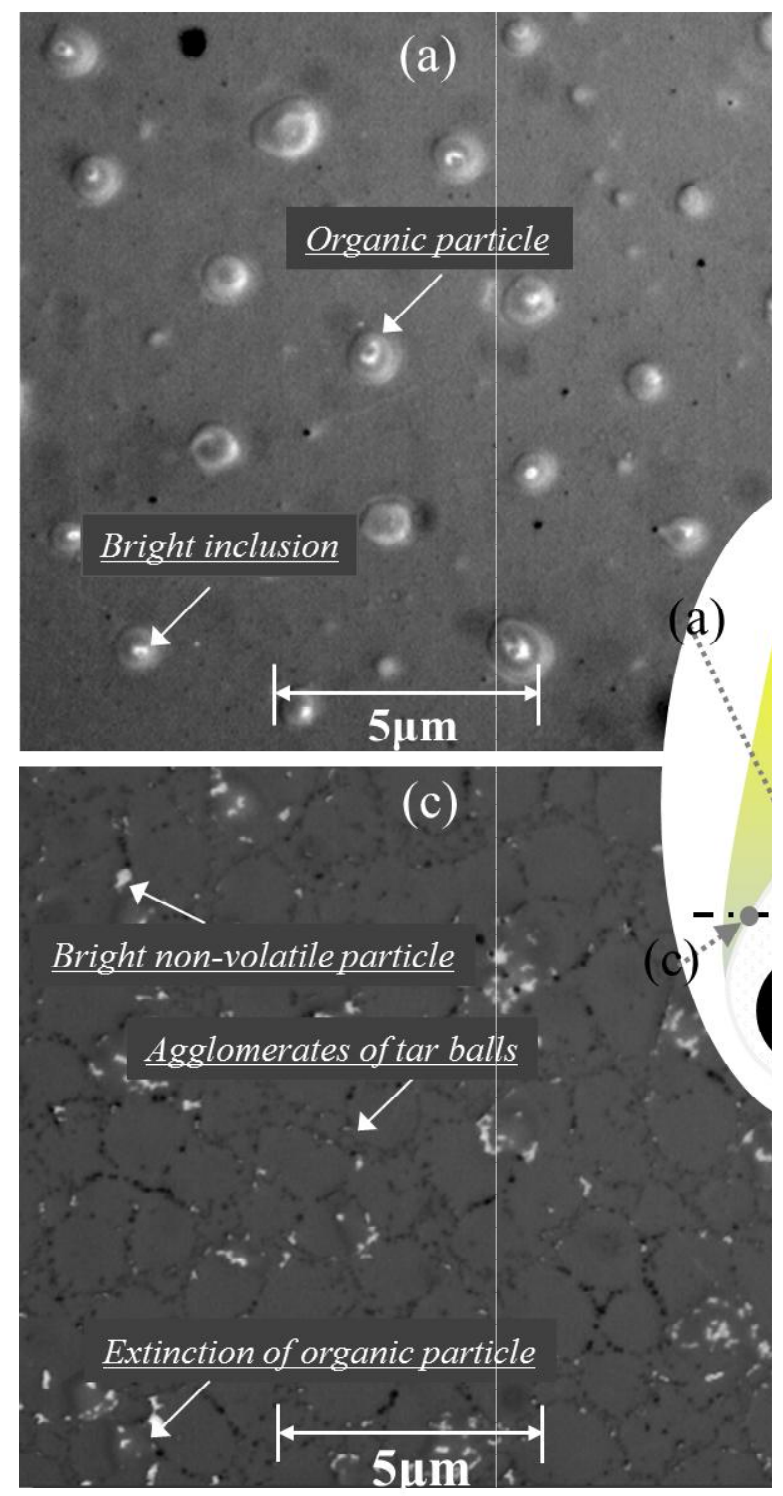

Fig.5.Morphology of carbonaceous particles formed in a flame: (a) aged organic particles with inclusions; (b) non-volatile particles with tar balls; (c) agglomerates of tar ballswith extinct organic particles; and (d) agglomerates of soot particles

\section{Direct observation of combustion behavioursof raw and torrefied sludge particles}

The raw and torrefiedsewage sludge particles in both size ranges $(150-215 \mu \mathrm{m}$ and $255-300$ $\mu \mathrm{m})$ were burned at the same hot gas temperature but different oxygen concentrations. The sequential combustion process ofa burning pulverised biomass particle is described in the 
superimposed images in Figure6. The particle is immediately heated up in the hot gas flow and a volatile flame appears within a few milliseconds, followed by the release of volatile matter on the surface and subsequent char combustion.As the oxidising environment was increased, the particles ignited faster with a shorter duration of volatile combustion and a higher probability of overlapping combustion before the flame extinguished.

The surrounding environment clearly affected the flame shape and luminosity between the particles. In the small particle group $(150-215 \mu \mathrm{m})$, the raw sludge particles burned with an invisible flame or an apparently low luminousvolatilecloud.The flame appearance can be explained by the low tar content in the small particle group, the $\mathrm{H} / \mathrm{C}$ ratio in devolatilisation[51] and the high hydrogen-to-carbon ratio $(\mathrm{H} / \mathrm{C}=1.5)$ with a small amount of volatile phase. In contrast, the $\mathrm{H} / \mathrm{C}$ ratio of coal ranges from 0.2 to 0.8 , depending on the rank of the coal. Consequently, the small raw sludge particles exhibited an invisible flame. However, the complex and varied mechanisms of tar formation preclude a clear explanation of the tar formation process[52].

In thelarger particle group $(255-300 \mu \mathrm{m})$, the flame was elongated with a moderate intensity, but still might generateinsufficientradiative heat for combustion systems. It has been found that the soot flame intensities and flame sizesgenerated by the mosttorrefied sludge particleswere remarkably distinct from those of burning raw particles. In the following results, the quantitative combustion characteristicsof the raw and torrefied sludge particles are compared.In the images, apparent soot flamesare observed only on the torrefied particles,even in the small particle group.This might indicate thattorrefaction greatly improves the fuel combustion quality of the particles, but reduces the duration of volatile combustion by removing the volatile matter. The result is contrary to expectation,asalso explained in the next results. Theflames became larger with decreasing $\mathrm{O}_{2}$ concentration, as 
reported in previous studies $[37,53]$.

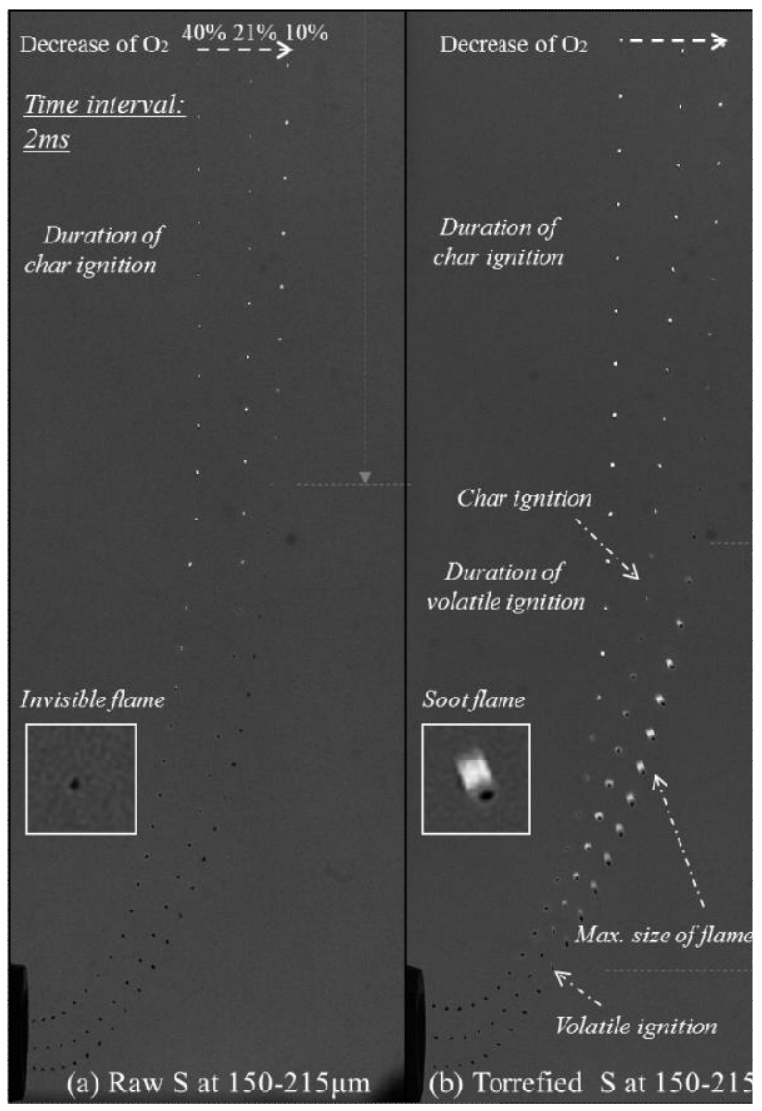

Fig.6.Sequential combustion on burning raw and torrefiedsludge particles at oxygen concentrations of 10-40\%: (a) Raw sludge particles(150-215 $\mu \mathrm{m})$; (b) Torrefied sludge particle $(150-215 \mu \mathrm{m})$; (c) Raw sludge particle $(255-300 \mu \mathrm{m})$; and (d) Torrefied sludge particle $(255-300 \mu \mathrm{m})$.

Figure7 presents the normalised optical intensity, measured from the centre of the particle along the y-axis. Theflame of the burningtorrefied particle comprised a transparent inner core and an outer shellwith possiblesooty formations. The inner flame was observed only under the $10 \%$ and $21 \% \mathrm{O}_{2}$ conditions. The outer flame increasedwith decreasing $\mathrm{O}_{2}$ concentration; this trend was attributed to slower soot oxidation. The soot particles with volatile matter tended to lift in an elongated formation underbuoyancy and transport. High-luminosity 
spherical flames appeared at oxygen concentrationsabove $21 \%$. The highest luminosity was observed in the presence of $21 \% \mathrm{O}_{2}$. As the $\mathrm{O}_{2}$ concentration increased from $21 \%$ to $40 \%$, the flame intensity decreased rapidly to approximately 0.5 .

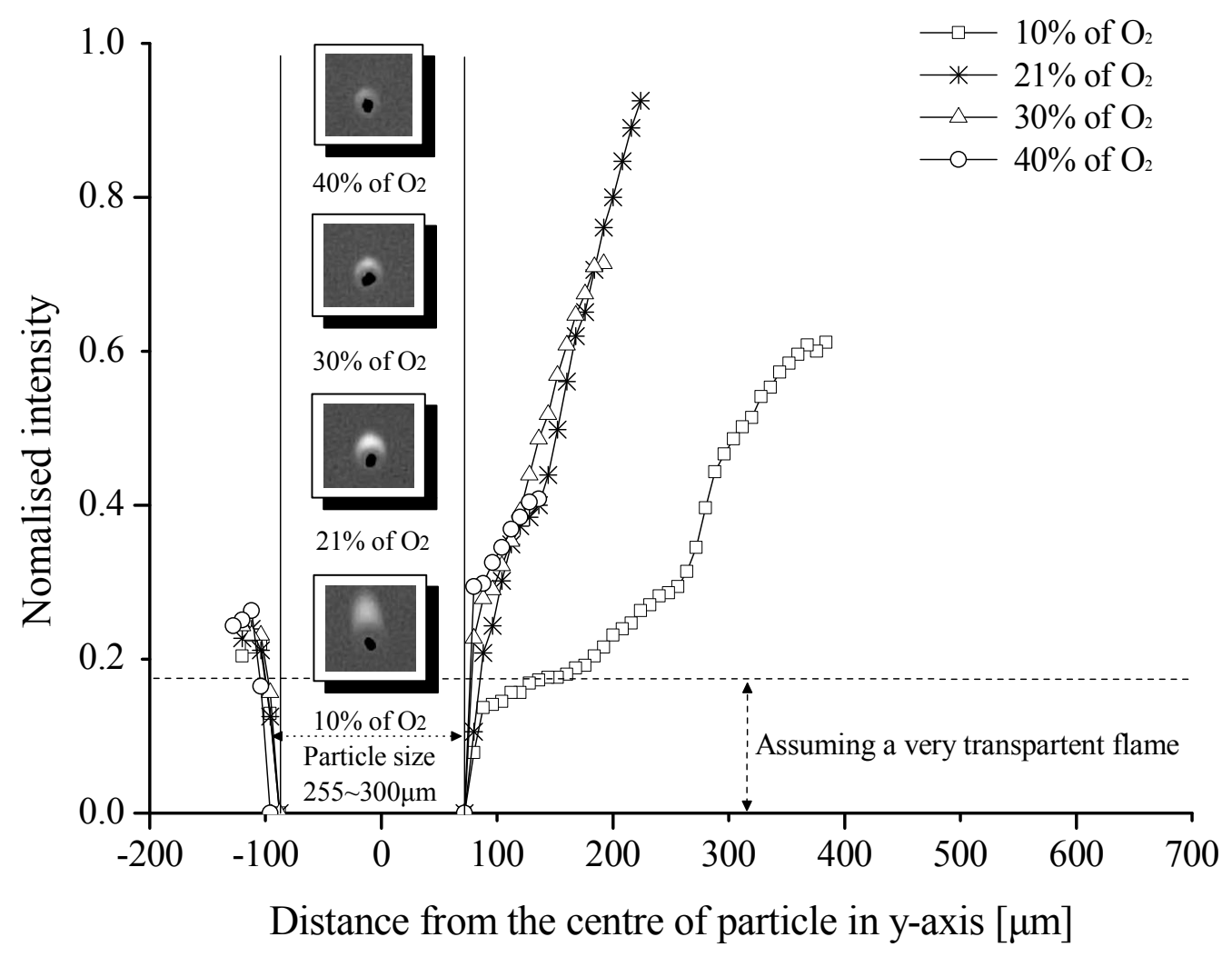

Fig.7. Optical normalised flame intensity versus y-axial distance from the centre of 255-300 $\mu \mathrm{m}$-diameter torrefied sludge particles. The most intense flames are spherical and appear at $21 \%$ oxygen concentration.

Comparativecombustion behavioursof three torrefied sludge particlesunder different thermal treatment conditions

According to the temperature and residence time of the thermal treatment, the chemical compositions of the fuel particles are varied. In particular, the degree of torrefaction will affect the combustion behavioursof the particles. Thechange might be remarkable in sewage 
sludge. In fact, the low fixed carbon and high ash contentsof raw sludge particles degrade the combustion quality and lengthen the ignition delay. Figure. 8 is a photographic series of threesmall-sized $(150-215 \mu \mathrm{m})$ torrefiedsludge particles, showing the histories of the volatile flames in a $21 \% \mathrm{O}_{2}$ atmosphere. The onset times of gaseous and char combustions are also shown. The luminosity wasthe highest onsewage particles torrefiedat $573 \mathrm{~K}$ for $30 \mathrm{~min}$ and was relatively low on particlestorrefied at $573 \mathrm{~K}$ for $10 \mathrm{~min}$. The ignition of particles in both treatments was almost equivalent at $26 \mathrm{~ms}$.However, the particlestorrefied at $473 \mathrm{~K}$ for $30 \mathrm{~min}$ exhibited an invisible flame until the onset of char combustion. Interestingly, all of the particles wereignited at the same onset time $(46-48 \mathrm{~ms}$ after the extinction of volatile combustion).

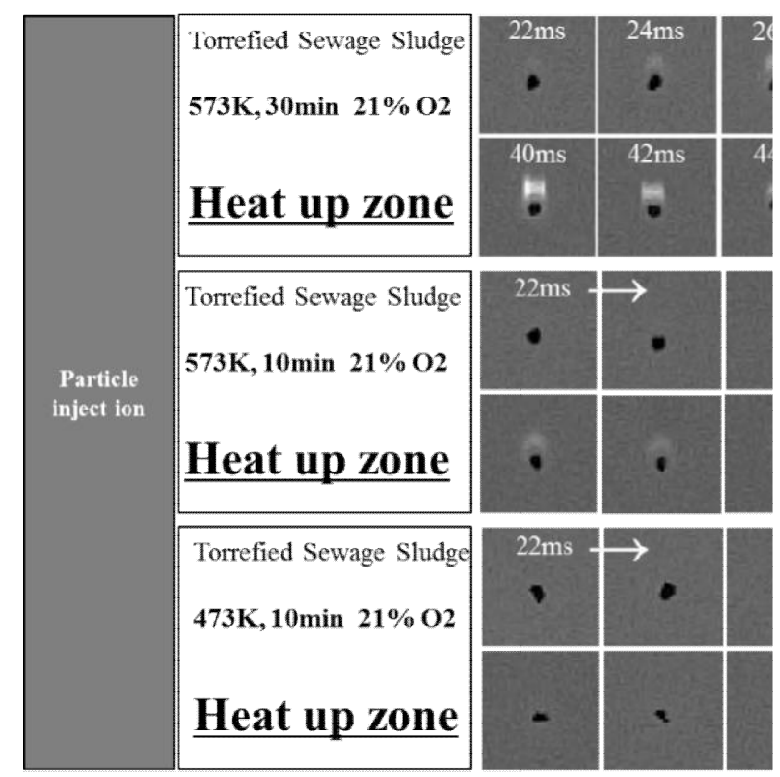

Fig.8.Photographic series of torrified sewage sludge (diameter $=150-215 \mu \mathrm{m})$ burningin a21\% $\mathrm{O}_{2}$ atmosphere: (a) Sewage sludge torrefiedat $573 \mathrm{~K}$ for30 min; (b) sewage sludge torrefiedat $573 \mathrm{~K}$ for $10 \mathrm{~min}$; and (c) sewage sludge torrefiedat $473 \mathrm{~K}$ for30 min. The luminosity of the flames depends on thetorrefaction degree of the particles. 
Figure 9plotsthe maximumradiiof the volatile flame and the normalisedintensitiesduring the burning ofsludge particlestorrefiedunder two conditions (10 min and $30 \mathrm{~min} ; 573 \mathrm{~K})$. For each torrefaction treatment, we analysed10 samplesand the standard deviation were calculated.For the flame sheet model, we assumed and calculated the concentric flame as the spherical flame. The volatile flame area $\left(\mathrm{A}_{\mathrm{f}}\right)$ was calculated by summing the corresponding area $\left(\mathrm{dA}_{\text {pixel }}\right)$, which was obtained from the pixels in the flame image. The effective flame radius $\left(R_{\text {eff }}\right)$ is calculated from the following equation, where $R_{p}$ is the particle radius

$$
R_{\text {eff }}=\sqrt{\frac{1}{\pi} \cdot\left(A_{f}+\pi R_{p}^{2}\right)} \text {, where } A_{f}=\int d A_{\text {pixel }}
$$

The intensities of volatile flames for the four particles wereanalysed by image processing, which was measured from an averaged value of a grayscale image. The image was converted into the grayscale image from a numerical data matrix. In the process, each pixel in the image has different values in a range of 0 to 255 and numerical background values, which were more or less than 65 , are extracted from the images. Finally, the intensity of the flame was divided by the maximum value of grayscale (255).

The profiles confirm variability in the flame structures, which mayexplainthe discrepancy in the burning characteristics. Under the same conditions of particle size $(255-300 \mu \mathrm{m})$ and $\mathrm{O}_{2}$ concentration $(10 \%)$, themaximum apparent effective diameter of the flame was approximately $500-600 \mu \mathrm{mfor}$ the more torrefied particles $(30 \mathrm{~min}$ at $573 \mathrm{~K}$ ) and $370-420$ $\mu$ mfor the lesstorrefied particles ( $573 \mathrm{~K}$ at $10 \mathrm{~min}$ ). As the $\mathrm{O}_{2}$ concentration increased to $20 \%$, the effective flame diameters of the more torrefied particle $(573 \mathrm{~K}$ at $30 \mathrm{~min})$ and the less torrefied particle $(573 \mathrm{~K}$ at $10 \mathrm{~min})$ decreased by approximately $110 \mu \mathrm{m}$ and $70 \mu \mathrm{m}$, respectively. The residence time is an important influencer of the flame diameter, because an 
appropriate torrefaction time enhances the chemical conversion for the reaction rate and soot formation. The flame intensity, which might be strongly related to the soot volume fraction,was lower on the moretorrefied sludge particles than on the lesstorrefied particles (0.51-0.62 vs. $0.27-0.3$ at $\mathrm{O}_{2}$ concentrations of $\left.10-21 \%\right)$.

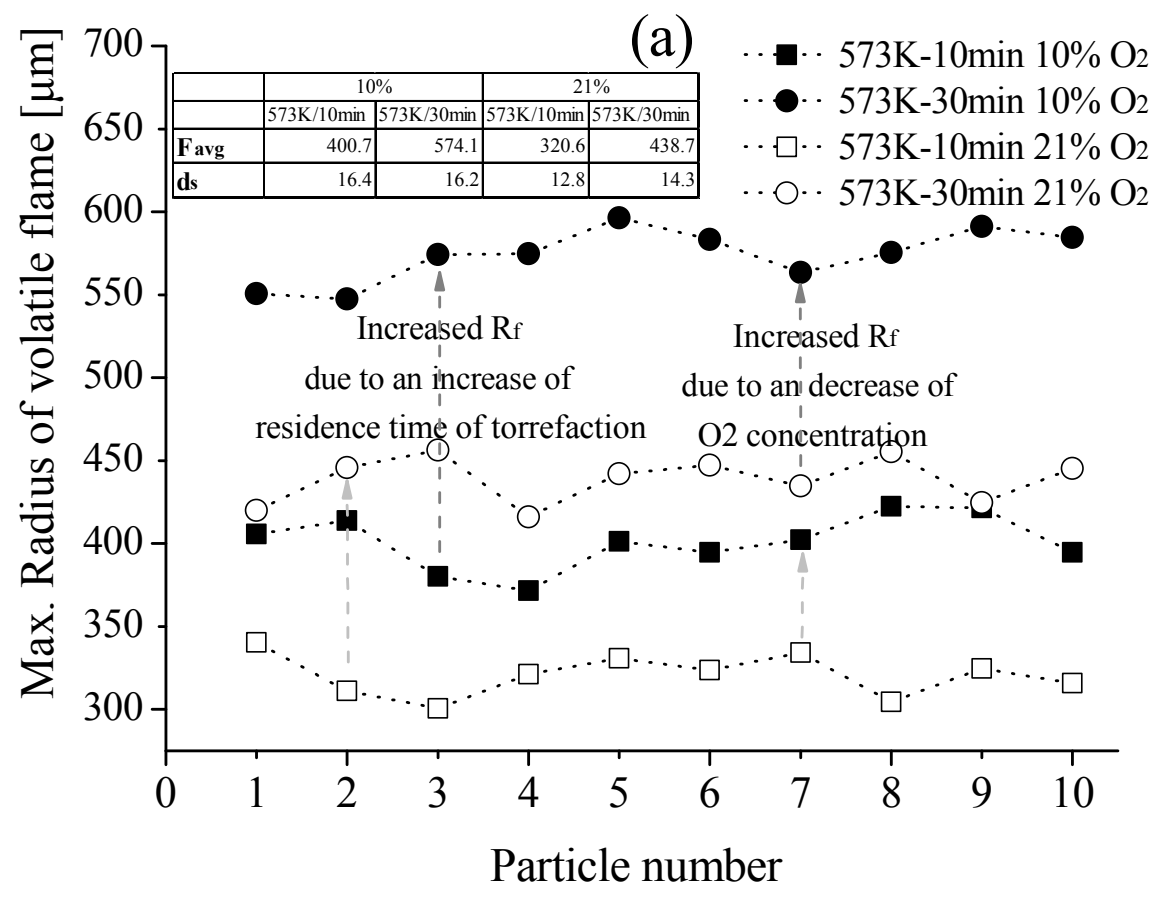




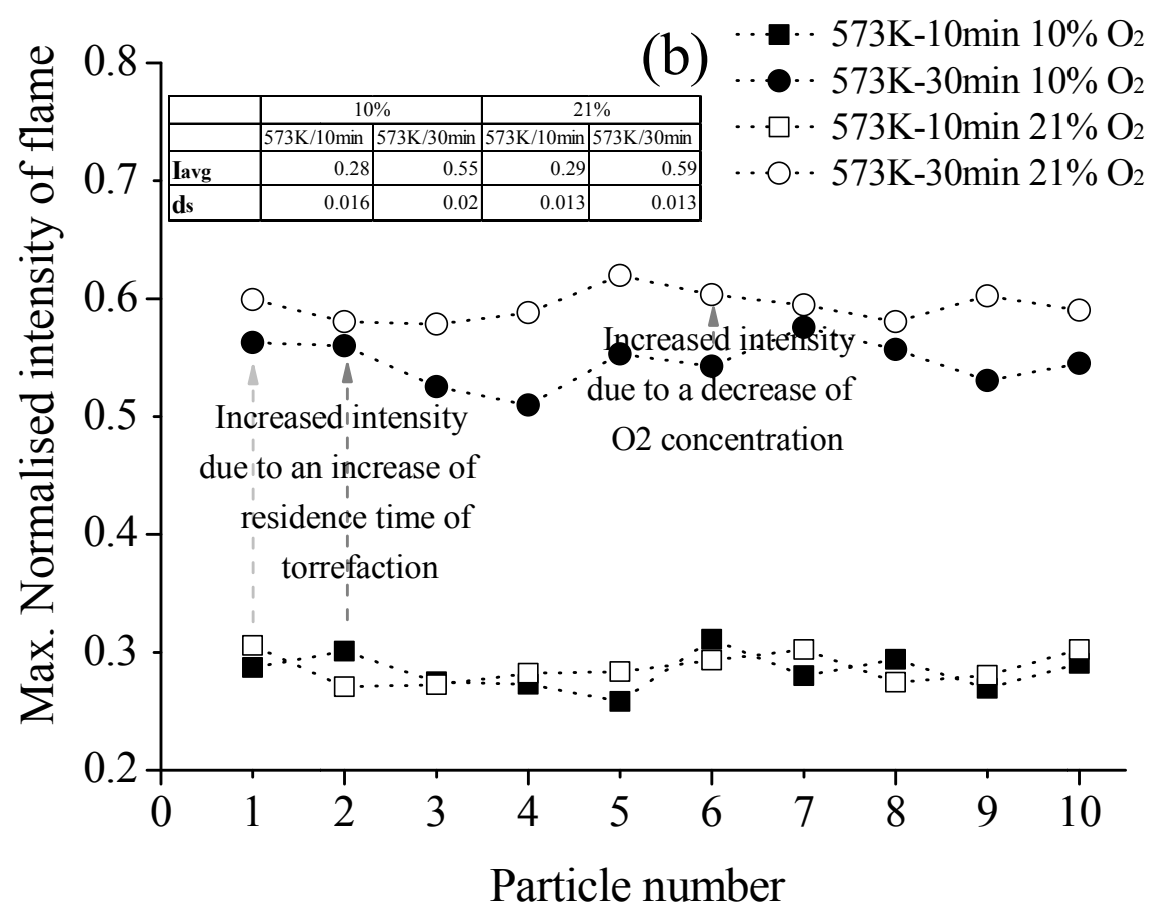

(c)
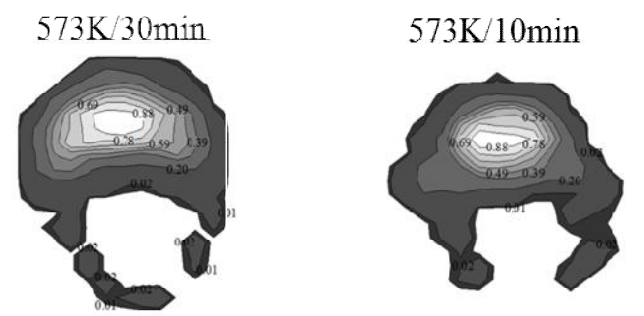

Figure 9.Volatile flamestructure on torrefied particles in $\mathrm{O}_{2}$ atmospheres of $10 \%$ and $20 \%$ : (a) Maximum radius of volatile flames (b) Normalised intensity of flames; and (c) Image analysis of volatile flames. Each panel shows the variation in flame size and intensity on sludge particlestorrefied under different conditions. 


\section{Discrepancy of volatile flames-time histories onthe most and least torrefied particles}

From ourresults, we canquantify thedevelopment of the burning particles associated with their volatile flames from initial ignition to flame extinction. We might also understand how the chemical reactions of the differentlytorrefied particles contribute tothe ratio of the effective flame radius to particle size.Figure10 shows thehistories of the burning behaviours of 5 particles in the larger size group $(255-300 \mu \mathrm{m})$. Generally, the physical structure of the volatile flame is determined by the volume fractionof the gaseous phase and soot particles. The reaction rates of these phases depend on theirchemical compositions and theparticle temperature. Here, the particlestorrefiedby different treatments differed in theirtorrefactiontemperatures, but wereidentical in size.

Beyond the peak in Fig. 10, the ratio of the effective flame radius to particlesize narrows between thedifferently torrefiedparticles. The discrepancyappears before the peak; the radius of the less torrefied particles, with a low soot flame,decreasesby up to 0.75 . This phenomenon might be related to the early-stage presence of soot particles, because the more torrefied sludge particles ( $573 \mathrm{~K}$ at $30 \mathrm{~min}$ ) have a higher fixed carbon than the less torrefied particles $(573 \mathrm{~K}$ at $10 \mathrm{~min})$. The flame intensity of the less torrefied particlesreduced over the combustion duration.However, theseparticlescontainedmore volatile matter than the highly torrefied particles, which would have enlarged their flames.Consequently, the variable radii and flame intensities aredominated by the different reaction rates with soot formationinthe early stage. In turn, the variable rates reflect the different chemical and physical compositions of the particles. However,this physical phenomenon requires validating in quantitative analyses of the soot volume fraction, which is beyond the scope of this study. The diffusion flames of the raw and strongly torrefied particles (473K for $30 \mathrm{~min}$ )were not clearly detected in the volatile-flametime histories.In other words, the raw sludge particles and 
thosetorrefiedunder inappropriate pre-thermal conditions might be unsuitable for biomass fired combustion.

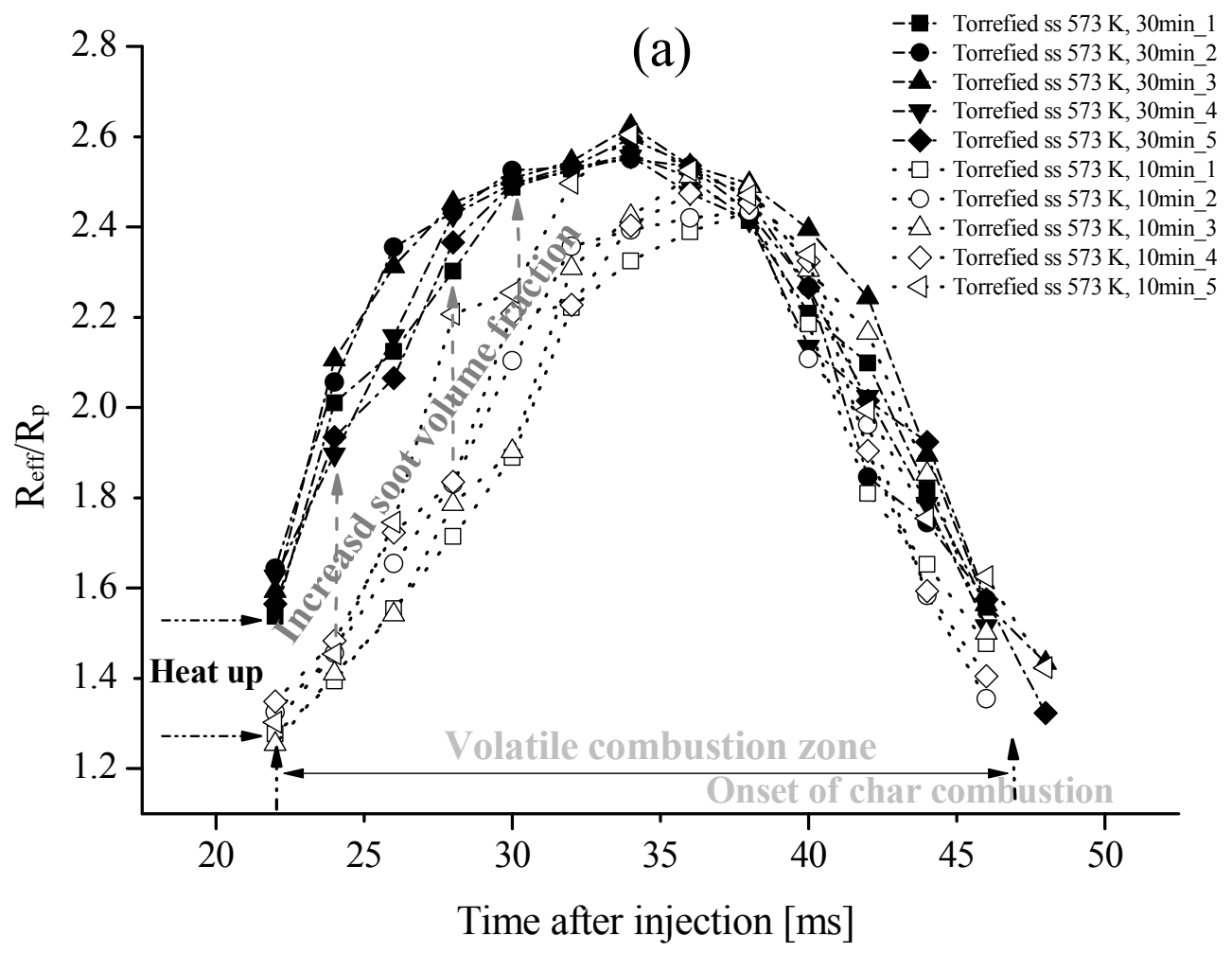




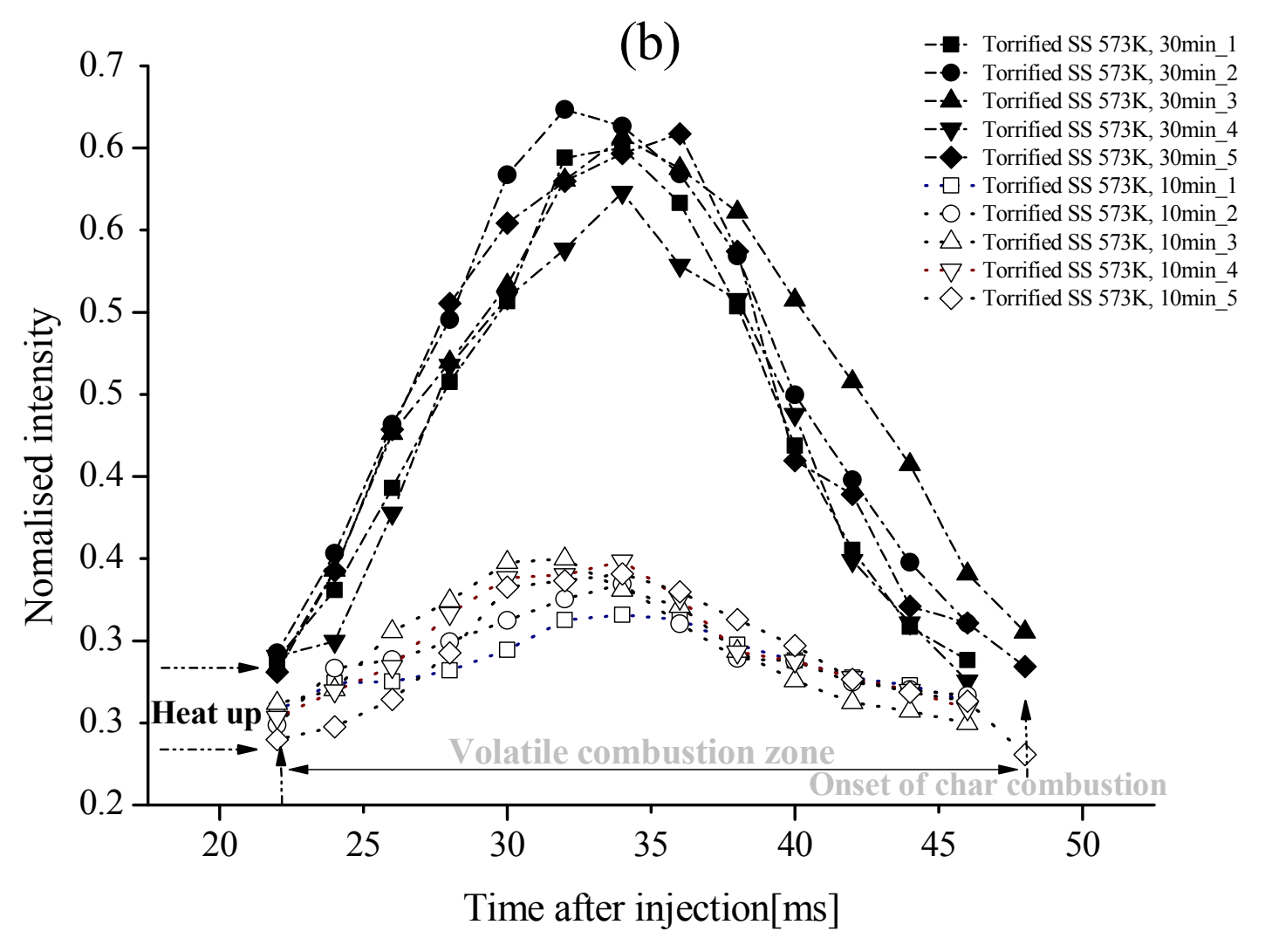

Fig.10. Apparent volatile flame structures of torrefied sewage sludge particles at $1340 \mathrm{~K}$ : (a) Radii of effective volatile flames relative to the particle diameter $(255-300 \mu \mathrm{m})$; and (b) normalised flame intensities of differentlytorrefied particles at $21 \% \mathrm{O}_{2}$ concentration. The graphs illustrate the early-stage discrepancy in the volatile flames between the differently torrefied sludge particles.

\section{Ignition delay and duration of volatile combustion on raw and torrefied sludge particles}

Figure11 presents the dissimilarityin the onset of initial ignition and the volatile combustion duration among thethreetorrefied particles and raw particlesof the same diameter(255-300 $\mu \mathrm{m})$.By discussing the discrepancy amongthe time parameters in particlestorrefied to different degrees, we can evaluate the combustion quality of the torrefied 
particles. The standard deviation of the volatile combustion duration of each particle was 1.79.2, sufficiently small for quantitative analysis. This statistical analysis is significant for verifying the flame structure and combustion behaviours. Thethree torrefiedparticles nearly coincided at approximately35-40 msafterthe average onset of volatile ignition,but the raw sludge particles exhibited a longer ignition delay (almost $76.2 \mathrm{~ms}$ ). Consequent to the extended ignitiondelay, the flame of the raw particles was extinguished at $140 \mathrm{~ms}$. However, thevolatile combustion duration scarcely differed between the raw and the most torrefied particles, despite the different volume fractions of volatile matter in the two particles. Conversely, the volatile combustion time was approximately $26 \mathrm{~ms}$ longer in the lesstorrefied sludge particles than in the moretorrefied particles.It appears that appropriate torrefaction can improve the quality of solid fuel particlesand increase the radiative energy from the soot flame without reducing the combustion time.

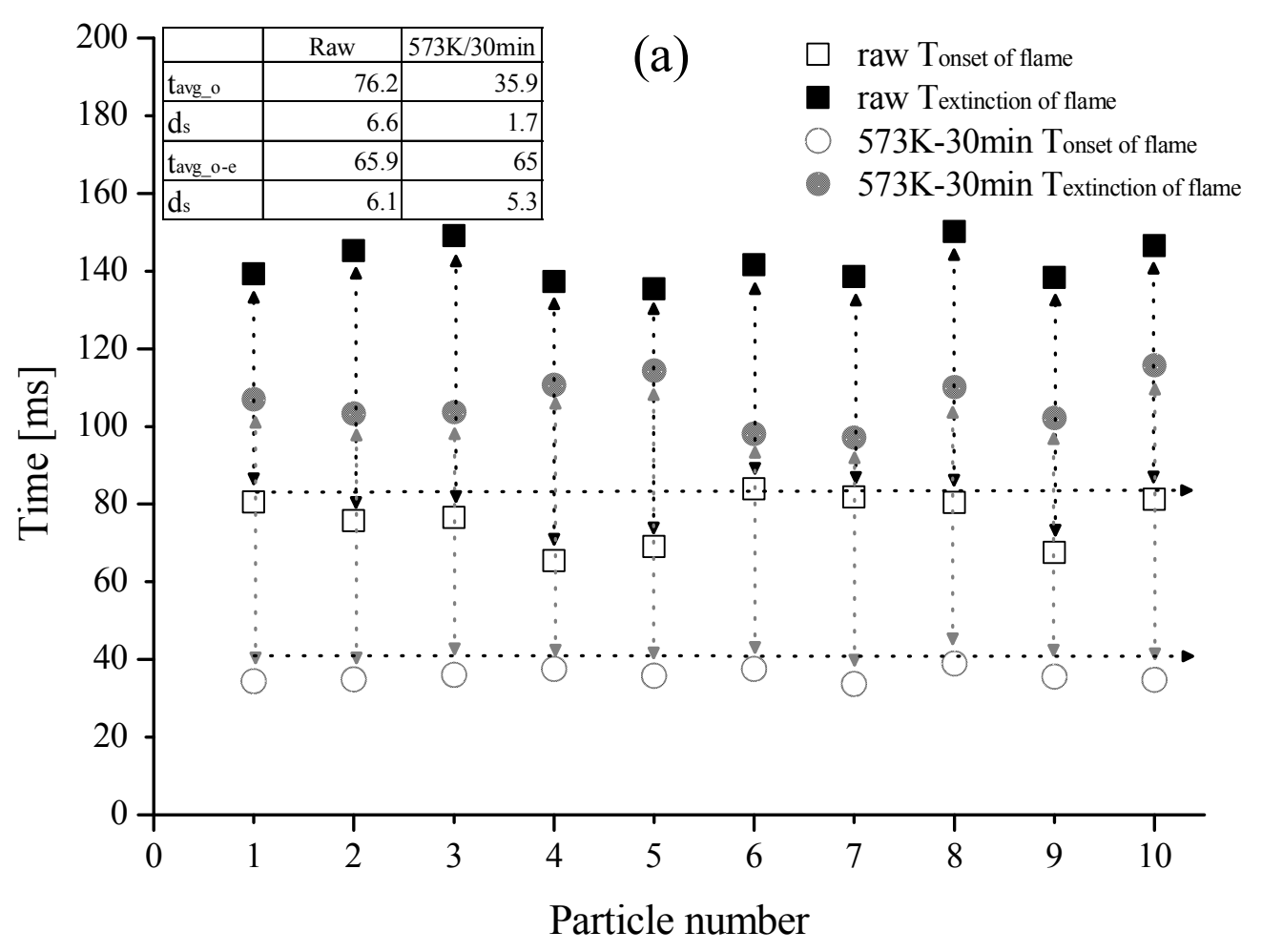




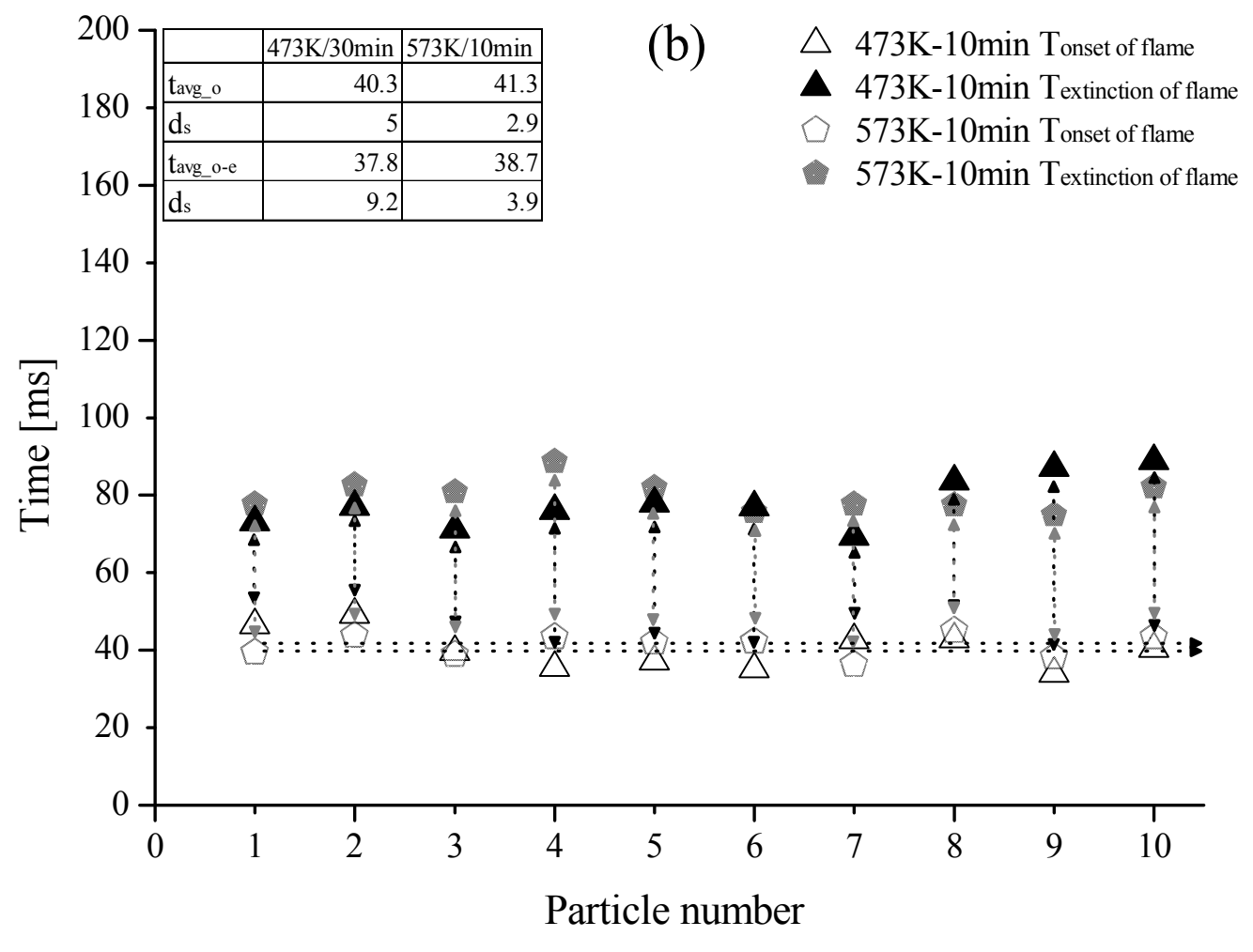




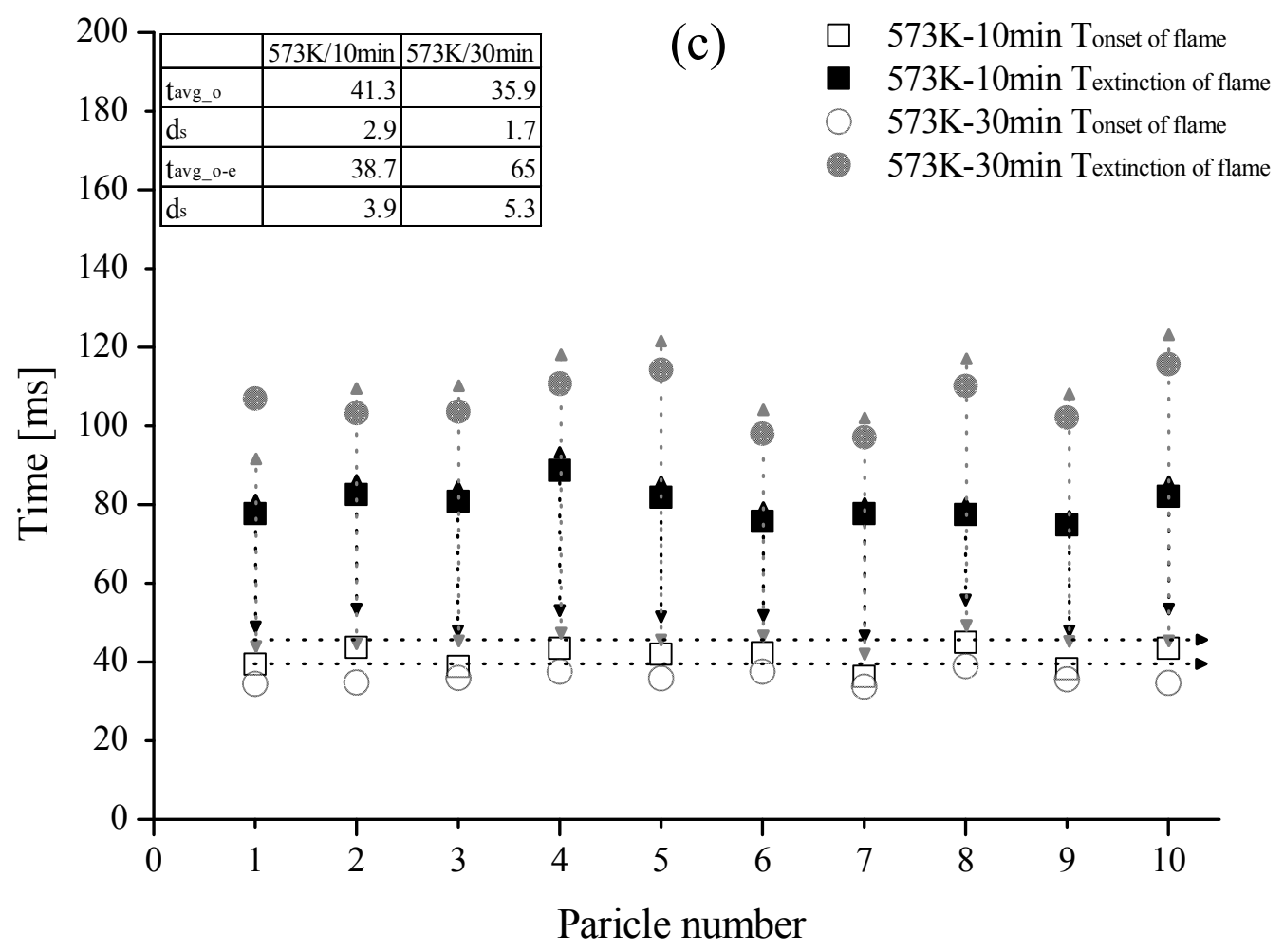

Fig.11.Ignition delays and durations of volatile combustions for four different sludge particles of the same diameter $(255 \sim 315 \mu \mathrm{m})$ : (a) raw and sludge particles torrefiedat573 $\mathrm{K}$ for30 min; (b) particles torrefied at $473 \mathrm{~K}$ and $573 \mathrm{~K}$ for 30 and $10 \mathrm{~min}$; and (c) sludge particles torrefied at $573 \mathrm{~K}$ for10 and 30 mins. The ignition delay is longest on the raw particles,but the duration of volatile combustion is identical on the raw and the more torrefied sludge particles

\section{Flame structures obtained from the effect of particle size and oxygen concentration}

The improved flame structures of the most torrefied sludge particlesalso enable high radiative heat transfer for combustion applications. According to the radiative heat transfer equation, this energy is proportional to the flame size and to the fourth power of the flame temperature.Figure 12 showsthe structural changes of the inner core and outer shell in the most torrefied particlesof both particle sizes. Here the $\mathrm{O}_{2}$ concentration was varied as 10,21 and $40 \%$.For both particle sizes and below $21 \% \mathrm{O}_{2}$ concentration, the inner core was 
extended in the flame and the $\mathrm{R}_{\mathrm{f}} / \mathrm{R}_{\mathrm{p}}$ rose steeply toward the peak. At $21 \% \mathrm{O}_{2}$ concentration, the $\mathrm{R}_{\mathrm{f}} / \mathrm{R}_{\mathrm{p}}$ depended on particle size, being 3.6 and 2.7 for particles in the 150 $215 \mu \mathrm{m}$ and $255-300 \mu \mathrm{mranges}$, respectively. The area of soot formation was larger at the higher particle diameters $(255-300 \mu \mathrm{m})$. The normalised intensitiesof the flames of $150-215$ $\mu$ mweremost similarat low $\mathrm{O}_{2}$ concentrations (10 and 21\%)and dramatically decreased to below 0.1 at $40 \% \mathrm{O}_{2}$. On the other hand, the flame intensities of the $255-300 \mu \mathrm{m}$ particlesincreased as the $\mathrm{O}_{2}$ concentration increased from $10 \%$ to $21 \%$, where they peaked at 0.65 , then reduced to 0.52 at $40 \% \mathrm{O}_{2}$. The discrepancy in the intensity profilesof the $150-215$ $\mu \mathrm{m}$ and 255-300 $\mu$ mparticles might be related to the soot volume fraction, as thehigher carbon contents in the larger particlesform a more luminous flame. 

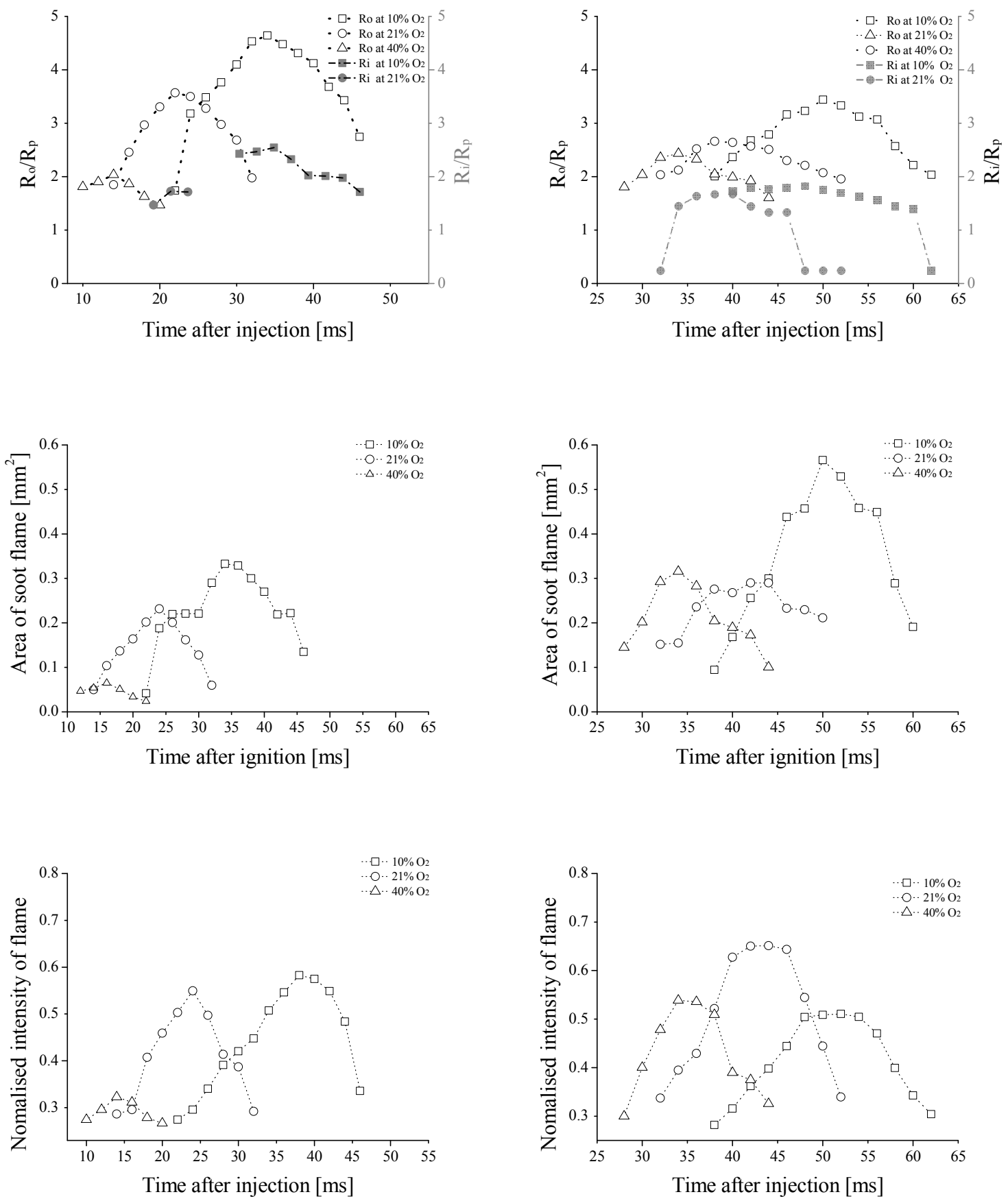

(a) (b)

Fig.12.Parametric physical flame parameters of the most torrefied sludge particles exposed to different oxygen concentrations. The particle size is (a) $150-215 \mu \mathrm{m}$ and (b) $255-300 \mu \mathrm{m}$.

Burnout characteristics derived from the particle size and oxygen concentration effects 
In very small pulverised particles, the ignition delay is shortened by the uniformtemperature gradient throughout the particle. Intra-particle temperature gradients establish in particles sized over $200 \mu \mathrm{m}$ [54]. In fact, the particle's surface temperature determines the heat flux generated to the centre of the particle. The temperaturedifferenceinduced by the particle size increases the heating time and reduces the devolatilisation rate. The most torrefiedsludge particles were investigated only for theirsize effect, as a clear soot flame was scarcely formed in small-diameter $(150-215 \mu \mathrm{m})$ raw and less torrefied sludge particles. Figure 13compares theaverage heat-up and volatile combustion durations of both size groupsburning under $\mathrm{O}_{2}$ concentrations of $10-40 \%$. The standard deviation of the 20 samples was calculated with the standard error (max. 0.3) using the rudimentary statistical analysis. The ignition delay and combustion time of the larger particles was almost double that of the smaller particles at the same oxygen concentration. We surmise that the particle temperature gradient plays animportant role in these time parameters. Theintra-particle effect requires further investigations on larger particle sizes. 


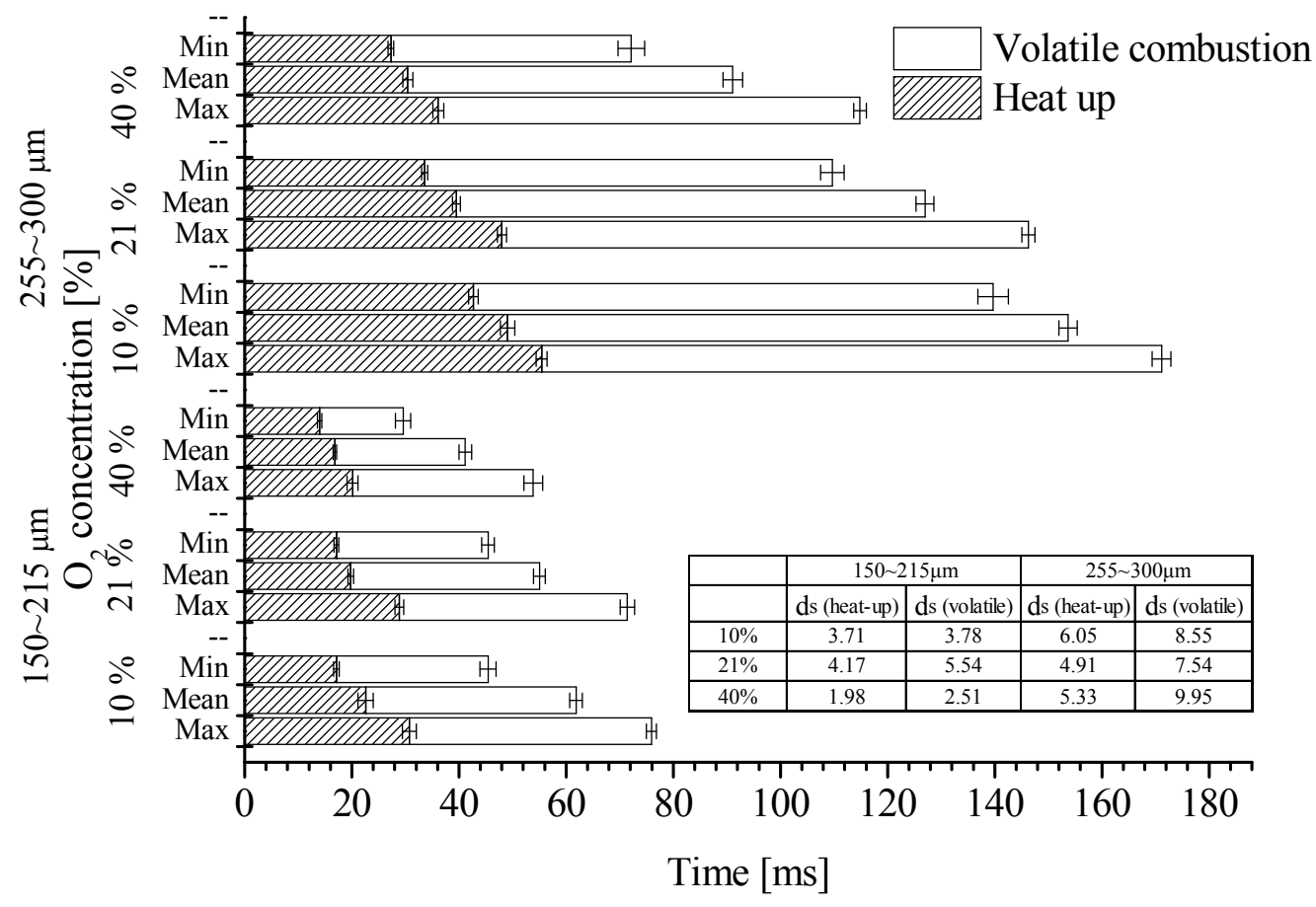

Fig. 13.Effect of particle $(573 \mathrm{~K} / 30 \mathrm{~min})$ size and oxygen concentration on ignition delay and volatile combustion duration.

\section{Conclusion}

Theflame structures of torrefied sewage sludge particles were experimentally observed inan environment of a hot gas stream and oxidising gases. The flames were compared with those of raw sewage sludge, which is generally regarded as a solid fuel particle with low combustion quality. The particles wereburned at rapid heating rates and high temperaturesthat typify actual volatile flames. The sludge particles were torrefied to different degrees and their ability to improve the combustion quality was assessed. From the results, it is believed that torrefactionimproves the flame size and intensity, which plays a significant role in radiative heat transfer and flame stability. These flame structures such as their size and intensity were 
determined by the torrefaction degree. These flame parameterswere significantly discrepant only in the early stages of particle combustion,when thereaction rates and soot formation were non-synchronous. The most torrefied sludge particles(prepared at $573 \mathrm{~K}$ for 30min)yielded very sooty flames with a fast ignition time even in the small diameter range $(150-215 \mu \mathrm{m})$. The duration of volatile combustion $(\sim 70 \mathrm{~ms})$ was almost equal in the raw and the most torrefied particles, despite the reduced volatile matter in the latter. For a comparative analysis of the torrefactiontreatments, a sufficiently high torrefactiontemperature and an appropriate residence time are required. The difference inonset of volatile ignitionbetween the raw and strongly torrefied samples might be attributable to lignin, which decomposes over a wide temperature range. Finally, when the oxygen concentration in the combustion was varied from 10 to $40 \%$, the highest flame intensitywas obtained ontorrefied particlesat $21 \%$ $\mathrm{O}_{2}$ concentration; moreover, the effective flame was enlarged in thesmaller particle group.This experimental result enables valuable discussions for improving the flame structures of torrefied particlesunderrapid heating rates and may also provide a modelling description of single torrefied particle combustion. 
Acknowledgments

The authors gratefully acknowledge support from the Korea Advanced Institute of Science and Technology (KAIST) and the Brain Korea 21+ project. Furthermore, we also acknowledge the effort of Jae Young Yoo(KAIST) and Dr Myung Won Seo and Dr Ho Won $\mathrm{Ra}$ (the Korea Institute of Energy Research) who actively contributed through sample preparation. 
References

[1] Karlström, O., A. Brink, E. Biagini, M. Hupa and L. Tognotti (2013). "Comparing reaction orders of anthracite chars with bituminous coal chars at high temperature oxidation conditions." Proceedings of the Combustion Institute34(2): 2427-2434.

[2] Li, J., M. C. Paul, P. L. Younger, I. Watson, M. Hossain and S. Welch (2016). "Prediction of high-temperature rapid combustion behaviour of woody biomass particles."Fuel165: 205214.

[3] Yuan, Y., S. Li, G. Li, N. Wu and Q. Yao (2014). "The transition of heterogeneoushomogeneous ignitions of dispersed coal particle streams." Combustion and Flame161(9): 2458-2468.

[4] Simões, G., D. Magalhães, M. Rabaçal and M. Costa "Effect of gas temperature and oxygen concentration on single particle ignition behavior of biomass fuels." Proceedings of the Combustion Institute.

[5] Trubetskaya, A., P. A. Jensen, A. D. Jensen, A. D. Garcia Llamas, K. Umeki, D. Gardini, J. Kling, R. B. Bates and P. Glarborg (2016). "Effects of several types of biomass fuels on the yield, nanostructure and reactivity of soot from fast pyrolysis at high temperatures." Applied Energy 171: 468-482.

[6] Septien, S., S. Valin, M. Peyrot, C. Dupont and S. Salvador (2014). "Characterization of char and soot from millimetric wood particles pyrolysis in a drop tube reactor between $800{ }^{\circ} \mathrm{C}$ and $1400{ }^{\circ} \mathrm{C} . "$ Fuel121: 216-224.

[7] Kobayashi, H., J. B. Howard and A. F. Sarofim (1977). "Coal devolatilization at high temperatures."Symposium (International) on Combustion 16(1): 411-425.

[8] Levendis, Y. A., K. Joshi, R. Khatami and A. F. Sarofim (2011). "Combustion behavior in air of single particles from three different coal ranks and from sugarcane

bagasse."Combustion and Flame158(3): 452-465.

[9] Riaza, J., R. Khatami, Y. A. Levendis, L. Álvarez, M. V. Gil, C. Pevida, F. Rubiera and J. J. Pis (2014). "Combustion of single biomass particles in air and in oxy-fuel conditions."Biomass and Bioenergy64: 162-174.

[10] Magdziarz, A. and S. Werle (2014). "Analysis of the combustion and pyrolysis of dried sewage sludge by TGA and MS."Waste Management34(1): 174-179.

[11] Ryu, C. and D. Shin (2013). "Combined Heat and Power from Municipal Solid Waste: Current Status and Issues in South Korea." Energies6(1): 45.

[12] Kijo-Kleczkowska, A., K. Środa, M. Kosowska-Golachowska, T. Musiał and K. Wolski (2015). "Mechanisms and kinetics of granulated sewage sludge combustion." Waste Management46: 459-471.

[13] Dogru, M., A. Midilli and C. R. Howarth (2002). "Gasification of sewage sludge using a throated downdraft gasifier and uncertainty analysis."Fuel Processing Technology75(1): 5582.

[14] Sands, P. and J. Peel (2012). Principles of international environmental law, Cambridge University Press.

[15] Pourcher, A.-M., P.-B. Françoise, F. Virginie, G. Agnieszka, S. Vasilica and M. Gérard (2007). "Survival of faecal indicators and enteroviruses in soil after land-spreading of municipal sewage sludge."Applied Soil Ecology35(3): 473-479.

[16] Merrington, G., I. Oliver, R. Smernik and M. McLaughlin (2003). "The influence of sewage sludge properties on sludge-borne metal availability."Advances in Environmental Research8(1): 21-36.

[17]Donatello, S. and C. R. Cheeseman (2013). "Recycling and recovery routes for 
incinerated sewage sludge ash (ISSA): A review." Waste Management33(11): 2328-2340. [18] Miller, B., R. Kandiyoti and D. Dugwell (2004). "Trace element behavior during cocombustion of sewage sludgewith polish coal." Energy \& Fuels18(4): 1093-1103.

[19] Fraissler, G., M. Jöller, H. Mattenberger, T. Brunner and I. Obernberger (2009). "Thermodynamic equilibrium calculations concerning the removal of heavy metals from sewage sludge ash by chlorination." Chemical Engineering and Processing: Process Intensification48(1): 152-164.

[20] Hu, Y., J. Wang, K. Deng and J. Ren (2014). "Characterization on Heavy Metals Transferring into flue gas during Sewage Sludge Combustion."Energy Procedia61: 28672870.

[21] Chan, C., C. Q. Jia, J. W. Graydon and D. W. Kirk (1996). "The behaviour of selected heavy metals in MSW incineration electrostatic precipitator ash during roasting with chlorination agents."Journal of Hazardous Materials50(1): 1-13.

[22]Jakob, A., S. Stucki and P. Kuhn (1995). "Evaporation of Heavy Metals during the Heat Treatment of Municipal Solid Waste Incinerator Fly Ash."Environmental Science \& Technology29(9): 2429-2436.

[23] Su, Y., W. Zhu, M. Gong, H. Zhou, Y. Fan and B. Amuzu-Sefordzi (2015). "Interaction between sewage sludge components lignin (phenol) and proteins (alanine) in supercritical water gasification."International Journal of Hydrogen Energy40(30): 9125-9136.

[24] Timothy, L. D., D. Froelich, A. F. Sarofim and J. M. Béer (1988). "Soot formation and burnout during the combustion of dispersed pulverized coal particles." Symposium (International) on Combustion21(1): 1141-1148.

[25] Fletcher, T. H., J. Ma, J. R. Rigby, A. L. Brown and B. W. Webb (1997). "Soot in coal combustion systems." Progress in Energy and Combustion Science23(3): 283-301.

[26] Saastamoinen, J., M. Aho, A. Moilanen, L. H. Sørensen, S. Clausen and M. Berg (2010). "Burnout of pulverized biomass particles in large scale boiler - Single particle model approach."Biomass and Bioenergy34(5): 728-736.

[27] Saadon, S., Y. Uemura and N. Mansor (2014). "Torrefaction in the presence of oxygen and carbon dioxide: the effect on yield of oil palm kernel shell." Procedia Chemistry9: 194201.

[28] Tran, K.-Q., T. N. Trinh and Q.-V. Bach (2016). "Development of a biomass torrefaction process integrated with oxy-fuel combustion." Bioresource technology199: 408-413.

[29] Van der Stelt, M., H. Gerhauser, J. Kiel and K. Ptasinski (2011). "Biomass upgrading by torrefaction for the production of biofuels: A review." Biomass and bioenergy35(9): 37483762 .

[30] Bridgeman, T., J. Jones, I. Shield and P. Williams (2008). "Torrefaction of reed canary grass, wheat straw and willow to enhance solid fuel qualities and combustion properties."Fuel87(6): 844-856.

[31] Kihedu, J. (2015). "Torrefaction and Combustion of Ligno-Cellulosic Biomass."Energy Procedia75: 162-167.

[32] Bach, Q.-V., K.-Q. Tran, Ø. Skreiberg and T. T. Trinh (2015)."Effects of wet torrefaction on pyrolysis of woody biomass fuels."Energy 88: 443-456.

[33] Chew, J. and V. Doshi (2011). "Recent advances in biomass pretreatment-Torrefaction fundamentals and technology." Renewable and Sustainable Energy Reviews15(8): 4212-4222. [34] Yang, H., R. Yan, H. Chen, D. H. Lee and C. Zheng (2007). "Characteristics of hemicellulose, cellulose and lignin pyrolysis."Fuel86(12): 1781-1788. 
[35] Mock, C., H. Lee, S. Choi and V. Manovic (2016). "Combustion Behavior of Relatively Large Pulverized Biomass Particles at Rapid Heating Rates."Energy \& Fuels30(12): 1080910822.

[36] Bharadwaj, A., L. L. Baxter and A. L. Robinson (2004). "Effects of intraparticle heat and mass transfer on biomass devolatilization: experimental results and model predictions." Energy \& fuels 18(4): 1021-1031.

[37] Lee, H. and S. Choi (2015). "An observation of combustion behavior of a single coal particle entrained into hot gas flow." Combustion and Flame162(6): 2610-2620.

[38] Lee, H. and S. Choi (2016). "Motion of single pulverized coal particles in a hot gas flow field."Combustion and Flame169: 63-71.

[39] Choi, S. and C. H. Kruger (1985). "Modeling coal particle behavior under simultaneous devolatilization and combustion."Combustion and Flame61(2): 131-144.

[40] Khatami, R. and Y. A. Levendis (2011). "On the deduction of single coal particle combustion temperature from three-color optical pyrometry."Combustion and Flame158(9): $1822-1836$.

[41] McLean, W., D. Hardesty and J. Pohl (1981). Direct observations of devolatilizing pulverized coal particles in a combustion environment. Symposium (International) on Combustion, Elsevier.

[42] Ishiguro, T., Y. Takatori and K. Akihama (1997). "Microstructure of diesel soot particles probed by electron microscopy: First observation of inner core and outer shell." Combustion and Flame 108(1): 231-234.

[43] Ma, J., T. Fletcher and B. Webb (1996). Conversion of coal tar to soot during coal pyrolysis in a post-flame environment.Symposium (International) on Combustion, Elsevier. [44] Pósfai, M., A. Gelencsér, R. Simonics, K. Arató, J. Li, P. V. Hobbs and P. R. Buseck (2004). "Atmospheric tar balls: Particles from biomass and biofuel burning." Journal of Geophysical Research: Atmospheres109(D6): n/a-n/a.

[45] Pósfai, M., R. Simonics, J. Li, P. V. Hobbs and P. R. Buseck (2003). "Individual aerosol particles from biomass burning in southern Africa: 1. Compositions and size distributions of carbonaceous particles." Journal of Geophysical Research: Atmospheres108(D13).

[46] Hand, J. L., W. Malm, A. Laskin, D. Day, T.-b. Lee, C. Wang, C. Carrico, J. Carrillo, J. P. Cowin and J. Collett (2005)."Optical, physical, and chemical properties of tar balls observed during the Yosemite Aerosol Characterization Study."Journal of Geophysical Research: Atmospheres110(D21).

[47] Novakov, T. and J. Penner (1993). "Large contribution of organic aerosols to cloudcondensation-nuclei concentrations."

[48] Engelhart, G., C. Hennigan, M. Miracolo, A. Robinson and S. N. Pandis (2012). "Cloud condensation nuclei activity of fresh primary and aged biomass burning

aerosol."Atmospheric Chemistry and Physics 12(15): 7285-7293.

[49] Kennedy, I. M. (1997). "Models of soot formation and oxidation."Progress in Energy and Combustion Science23(2): 95-132.

[50] Arora, P. and S. Jain (2015). "Morphological characteristics of particles emitted from combustion of different fuels in improved and traditional cookstoves." Journal of Aerosol Science82: 13-23.

[51] Tyler, R. J. (1980). "Flash pyrolysis of coals. Devolatilization of bituminous coals in a small fluidized-bed reactor."Fuel59(4): 218-226.

[52] Jüntgen, H. (1984). "Review of the kinetics of pyrolysis and hydropyrolysis in relation to the chemical constitution of coal." Fuel63(6): 731-737.

[53] Shaddix, C. R. and A. Molina (2009). "Particle imaging of ignition and devolatilization 
of pulverized coal during oxy-fuel combustion."Proceedings of the Combustion Institute 32(2): 2091-2098.

[54] Toporov, D. (2014). Combustion of pulverised coal in a mixture of oxygen and recycled flue gas, Elsevier. 